\title{
ACTION OF PROTEOLYTIC ENZYMES ON LIPOTROPINS AND ENDORPHINS: BIOSYNTHESIS, BIOTRANSFORMATION AND FATE
}

\author{
J. Peter H. Burbach \\ Rudolf Magnus Institute for Pharmacology, Medical Faculty, University of Utrecht, Vondellaan 6 , \\ 3521 GD, Utrecht, The Netherlands
}

\section{INTRODUCTION}

$\beta$-Lipotropin is a polypeptide hormone with lipolytic activity which was first identified in the anterior lobe of the pituitary gland ( $\mathrm{Li}, 1964$; $\mathrm{Li}$ et al., 1965; Chrétien and $\mathrm{Li}, 1967)$. $\beta$-Endorphin, which constitutes the 31 amino acids containing $\mathrm{COOH}$-terminal portion of $\beta$-lipotropin, was discovered later to exist as an individual peptide with potent opioid activities (Li and Chung, 1976; Bradbury et al., 1976b; Gráf et al., 1976a). The structural relationship between the two peptides made clear that $\beta$-lipotropin could serve as a precursor of biologically active peptides and pointed to the significance of the proteolytic enzymes responsible for the conversion process. Now it has been established that $\beta$-lipotropin and $\beta$-endorphin, together with adrenocorticotropin (ACTH), $\alpha$-melanotropin ( $\alpha$-melanocyte stimulating hormone, $\alpha-\mathrm{MSH})$ and other biologically active peptides, are derived from a single precursor protein, termed pro-opiomelanocortin by specific proteolytic processing (Mains et al., 1977; Chrétien et al., 1979; Herbert et al., 1980; Eipper and Mains, 1980).

Differences in proteolytic processing of pro-opiomelanocortin underly the existence of distinct sets of biologically active peptides derived from pro-opiomelanocortin. For instance, $\beta$-lipotropin, together with $\mathrm{ACTH}$ and a large peptide of the $\mathrm{NH}_{2}$-terminal portion is the major biosynthetic end product in the anterior pituitary (Mains and Eipper, 1978a,b; Herbert et al., 1980). However, in the intermediate lobe of the pituitary, in brain and presumably also in placenta and pancreas, main products are $\beta$-endorphin and $\gamma$-lipotropin, $\alpha$-melanotropin, corticotropin-like intermediate lobe peptide (CLIP) and several shorter $\mathrm{NH}_{2}$ terminal pro-opiomelanocortin fragments (Fig. 1) (Mains and Eipper, 1978a,b, 1979; Roberts et al., 1978; Crine et al., 1978, 1979; Eipper and Mains, 1981; Liotta and Krieger, 1980; Liotta et al., 1981; Smyth and Zakarian, 1982). These peptides all arise during a discrete proteolytic cleavage mechanism which is directed by paired basic amino acids. This type of proteolytic cleavage constitutes a universal mechanism in the biosynthesis of many biologically active peptides and proteins (Steiner et al., 1974, 1975, 1980) and is indicated as biosynthetic processing; the resulting fragments are generally considered as biosynthetic end products.

In addition to biosynthetic processing, proteolytic enzymes with different specificity act on biosynthetic end products and can generate shorter peptides with biological activities (e.g. Peach, 1977). The behaviorally active $\beta$-endorphin fragments $\alpha$-endorphin and $\gamma$-endorphin are examples of pro-opiomelanocortin peptides formed by proteolytic conversion of the endproduct $\beta$-endorphin (Austen et al., 1978a; Burbach et al., 1980a, 1981). Such proteolytic events, cleaving biosynthetic end products and producing biologically active peptides, may be indicated by biotransformation. Biotransformation does not employ a single type of proteolytic cleavage but different mechanisms leading to production or modification of biological activity can be distinguished. Finally, peptidases 


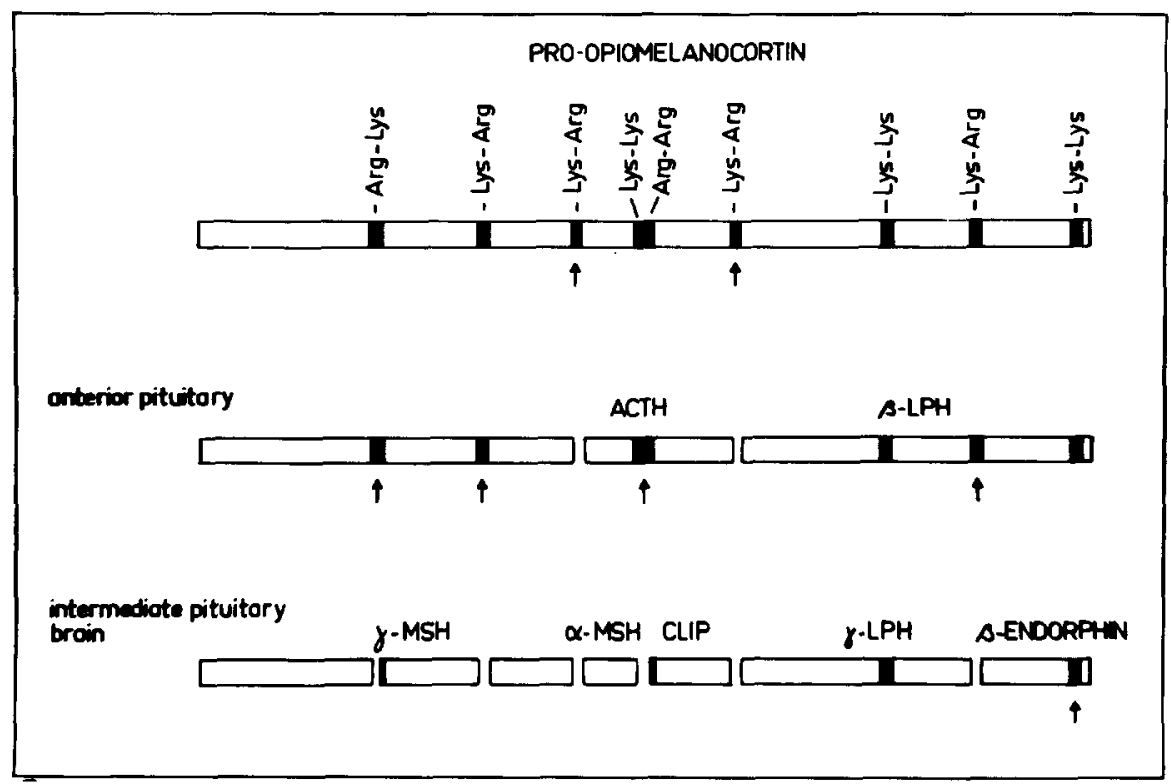

FiG. 1. The structural organization of pro-opiomelanocortin and its products of processing in the anterior and neurointermediate lobes of the pituitary gland and the brain. The arrows indicate the cleavages of paired basic amino acid residues (dark areas).

of various tissues and cellular compartments can mediate degradation and inactivation of peptides, while peptidases in blood and peripheral organs contribute to the disappearance of peptides in the circulation.

This article reviews the actions of proteolytic enzymes on $\beta$-lipotropin, $\beta$-endorphin and related peptides. The proteolytic processes are discussed from the viewpoint of production of peptides (i.e. biosynthesis and biotransformation) as well as inactivation and elimination of peptides (degradation and fate).

\section{STRUCTURE AND FORMS OF LIPOTROPINS AND ENDORPHINS}

The lipotropins and endorphins comprise a family of several biologically active peptides. The molecular forms by which they occur and display their biological activities are determined by the proteolytic cleavage of their precursors. Often the molecular forms of peptides by themselves are indicative for the types of proteolytic cleavage taking place. Structure and forms of lipotropins and endorphins are briefly reviewed below.

TABLE 1. Comparison of $\beta$-Lipotropins of Various Mammalian Species

\begin{tabular}{|c|c|c|c|c|}
\hline Species & $\begin{array}{l}\text { Number of } \\
\text { Residues }\end{array}$ & $\begin{array}{c}\text { Percentage } \\
\text { of Sequence } \\
\text { Homologous } \\
\text { with the Human } \\
\text { Sequence }\end{array}$ & $\begin{array}{c}\text { Sequence } \\
\text { Numbering } \\
\text { of } \beta \text {-Endorphin- } \\
(1-31)\end{array}$ & Reference \\
\hline human & 89 & & $\beta$-LPH-(59-89) & $\begin{array}{l}\text { Hsi et al., 1981; Spiess et al., 1982; } \\
\text { Seidah et al., 1982; Takahashi et al., } \\
\text { 1981; Whitfield } \text { et al., } 1982 .\end{array}$ \\
\hline porcine & 91 & 68 & $\beta$-LPH-(61-91) & $\begin{array}{l}\text { Gilardeau and Chrétien, 1972; Gráf et al., } \\
1974\end{array}$ \\
\hline ovine & 91 & 78 & $\beta$-LPH-(61-91) & Li et al., 1965; Gráf and Li, 1973 \\
\hline whale & 91 & 73 & $\beta$-LPH-(61-91) & Kawauchi et al., 1980a. \\
\hline bovine & 93 & 73 & $\beta-\mathrm{LPH}-(63-93)$ & $\begin{array}{l}\text { Lohmar and } \mathrm{Li}, 1967 \text {, Pankov, } 1973 ; \\
\mathrm{Li} \text { et al., 1977; Nakanishi et al., } 1979 .\end{array}$ \\
\hline rat & 71 & 79 & $\beta$-LPH-(41-71) & Drouin and Goodman, 1980. \\
\hline mouse & 71 & 77 & $\beta-\mathbf{L P H}-(41-71)$ & $\begin{array}{l}\text { Uhler and Herbert, 1983; Notake et al., } \\
1983 .\end{array}$ \\
\hline
\end{tabular}




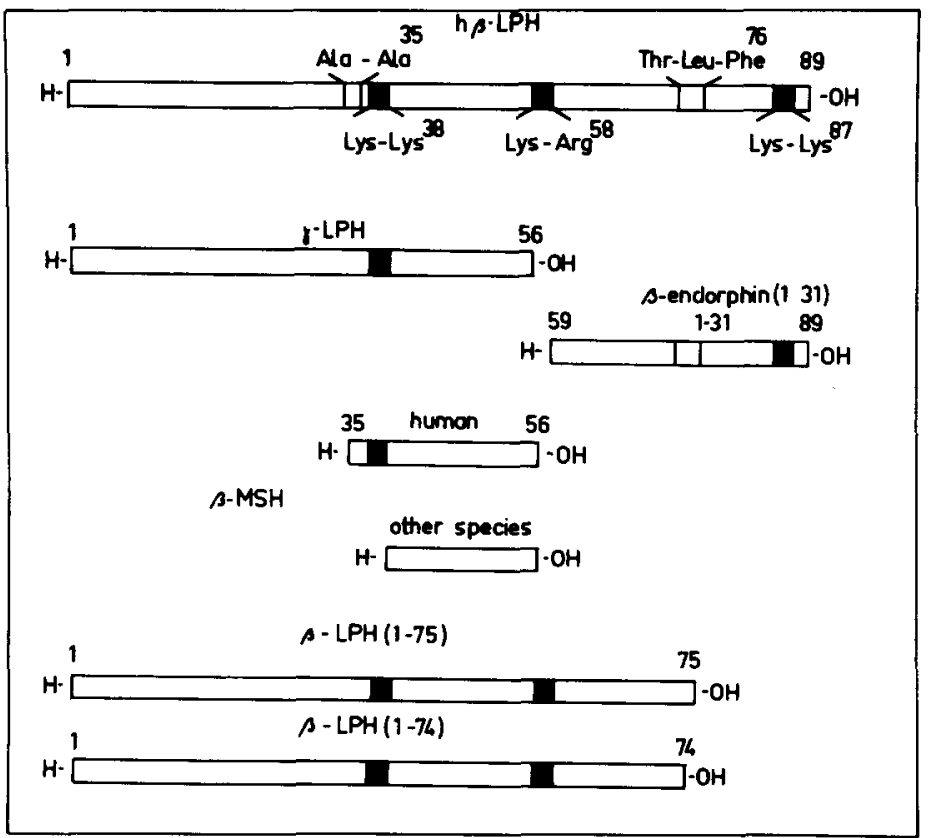

FIG. 2. $\beta$-Lipotropin and derived peptides. The structure of human $\beta$-lipotropin, h $\beta$-LPH-(1-89), is shown as representative for the $\beta$-lipotropins of mammalian species. The dark boxes represent pairs of basic amino acids; the open boxes indicate other characteristic sequences subject to proteolytic cleavage. For details of peptides related to $\beta$-endorphin-(1-31) see Fig. 3. The sequence of human $\beta$-lipotropin is:

H-Glu-Leu-Thr-Gly-Gln-Arg-Leu-Arg-Glu-Gly-Asp-Gly-Pro-Asp-Gly-Pro-Ala-Asp-Asp-

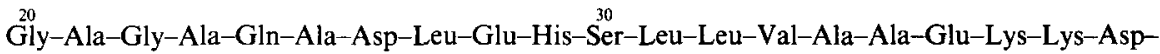
Glu-Gly-Pro-Tyr-Arg-Met-Glu-His-Phe-Arg-Trp-Gly-Ser-Pro-Pro-Lys-Asp-Lys-ArgTyr-Gly-Gly-Phe-Met-Thr-Ser-Glu-Lys-Ser-Gln-Thr-Pro-Leu-Val-Thr-Leu-Phe-Lys-AsnAla-Ile-Ile-Lys-Asn-Ala-Tyr-Lys-Lys-Gly-Glu-OH

\subsection{LIPOTROPINS}

\subsection{1. $\beta$-Lipotropin}

$\beta$-Lipotropin was first discovered in extracts of ovine pituitary glands $(\mathrm{Li}, 1964$; Birk and $\mathrm{Li}, 1964)$. In subsequent years the $\beta$-lipotropin of several other species has been purified and sequenced. Recently, amino acid sequences have also been deduced from nucleotide sequences of cloned genes or cDNAs encoding pro-opiomelanocortin. A comparison of $\beta$-lipotropins is presented in Table 1 . Not until recently was consensus reached concerning the $\mathrm{NH}_{2}$-terminal sequence of human lipotropin (Fig. 2); now data of amino acid and nucleotide sequence agree (Hsi et al., 1981; Spies et al., 1982; Seidah et al., 1982; Takahashi et al., 1981; Whitfield et al., 1982).

The various $\beta$-lipotropins vary in length from 71 residues (mouse, rat) to 93 residues (bovine) (Table 1), mainly due to differences in the $\mathrm{NH}_{2}$-terminal region. In general, this region is highly heterologous, while a high sequence homology is present in the 50 residues of the $\mathrm{COOH}$-terminal region of $\beta$-lipotropins.

\subsection{2. $\beta$-Lipotropin- $(1-77) /-(1-75)$}

The $\mathrm{COOH}$-terminally truncated form of porcine $\beta$-lipotropin $(\beta$-lipotropin-(1-77)) has been identified as product of $\beta$-lipotropin cleavage by pituitary and brain homogenates (Gráf and Kenessey, 1976; Gráf et al., 1979a,b). Dorsa et al. (1982) detected in rat pituitary a large peptide cross-reacting with an antiserum for the $\mathrm{COOH}$-terminus of $\gamma$-endorphin 
( $\beta$-endorphin-(1-17)) and suggested that it was related to this $\beta$-lipotropin-(1-77) (rat $\beta$-lipotropin-(1-56)). Recently, Burbach and Wiegant (1984) detected in human pituitaries a similar peptide in considerable amounts cross-reacting with a $\mathrm{COOH}$-terminal $\gamma$-endorphin antiserum (Loeber et al., 1979; Loeber and Verhoef, 1981). This peptide was only slightly smaller than $\beta$-lipotropin. By isolation and determination of amino acid composition it was shown that the $\mathrm{COOH}$-terminal tryptic fragment was $\beta$-endorphin$(10-17)$. These data indicated that this peptide was human $\beta$-lipotropin-(1-75). These studies suggest that human $\beta$-lipotropin-(1-75), porcine $\beta$-lipotropin-(1-77) and rat $\beta$-lipotropin-(1-56) are endogenously present in anterior pituitary tissue and point to the significance of proteolytic enzymes cleaving the (human) $\mathrm{Leu}^{75}-\mathrm{Phe}^{76}$ bond of $\beta$-lipotropin.

\subsection{3. $\gamma$-Lipotropin and $\beta$-Melanotropin}

Several $\mathrm{NH}_{2}$-terminal forms of lipotropins have been identified. The complete $\mathrm{NH}_{2}$-terminal portion resulting from cleavage of $\beta$-lipotropin at the (human) paired basic residues $\mathrm{Lys}^{57}-\mathrm{Arg}^{58}$ has been termed $\gamma$-lipotropin (Fig. 2). In most species having a intermediate pituitary lobe $\gamma$-lipotropin seems to be the most abundant form of $\mathrm{NH}_{2}$-terminal peptides derived from $\beta$-lipotropin. In addition, in several species peptides comprising the midportion of $\beta$-lipotropin have been detected. These peptides stimulate the pigmentation of amphibian skin and have been termed $\beta$-melanotropins ( $\beta$-MSH) (Lerner et al., 1954; Li, 1957) (Fig. 2). In the structure of $\beta$-lipotropin of several species, except mouse and rat, $\beta$-melanotropin is enclosed by two pairs of basic amino acid residues which can be cleaved during biosynthetic processing. A longer form of $\beta$-melanotropin, having $\mathrm{NH}_{2}$-terminally a tetrapeptide extension (Fig. 2) has been isolated from human pituitary glands (Harris and Lerner, 1957; Pickering and Li, 1963). However, it has been demonstrated that this form of human $\beta$-melanotropin is an extraction artifact (Scott and Lowry, 1974; Bloomfield et al., 1974; Bachelot et al., 1977; Tanaka et al., 1978a) possibly produced by cleavage by cathepsin D (Barát et al., 1979).

\subsection{ENDORPHINS}

\subsection{1. $\beta$-Endorphin}

$\beta$-Endorphin is the 31 amino acid containing $\mathrm{COOH}$-terminal portion of $\beta$-lipotropin. The peptide was found to have potent opiate-like activities (Bradbury et al., 1976b; Li and Chung, 1976; Loh et al., 1976; Cox et al., 1976; Van Ree et al., 1976). Since then $\beta$-endorphin has been subject to extensive research.

The structure of $\beta$-endorphin of a variety of species has been determined by isolation and amino acid sequencing of the peptide or via deduction from the nucleotide sequence of cloned cDNAs or a genomic fragment coding its precursor protein proopiomelanocortin. The structures are presented in Table 2 .

The various mammalian $\beta$-endorphins display strong homology. Differences occur only in position 23 (Ile or Val), 27 (Tyr or His) and 31 (Gln or Glu). A discrepancy in data on the structure of rat $\beta$-endorphin exists with respect to the amino acid in position 26 (Val or Ala) (Table 2), which may be due to a polymorphism, rat strain differences, or modification of nucleotides during cloning procedures (J. Drouin, personal communication).

Multiple forms of $\beta$-endorphin exist due to two types of modification. Firstly, the $\mathrm{NH}_{2}$-terminus of $\beta$-endorphin can be acetylated (Smyth and Zakarian, 1978, 1979; Zakarian and Smyth, 1979; Smyth et al., 1979). This acetylation inactivates the opiate-like properties of the peptide (Deakin et al., 1980). Acetyltransferase activities capable of acetylating the $\mathrm{NH}_{2}$-terminus of $\beta$-endorphin have been detected (Chappell et al., 1982; Glembotski, 1982b; O'Donohue, 1983). Secondly, the COOH-terminus of $\beta$-endorphin can be trimmed by proteolytic cleavage of the $\mathrm{Lys}^{28}-\mathrm{Lys}^{29}$ residues followed by carboxypeptidase B like removal of these basic amino acids (Mains and Eipper, 1982; Eipper and Mains, 1981). This cleavage is an extension of biosynthetic processing. $\beta$-Endorphins having His at position 27 , lose this residue due to proceeding carboxypeptidase action 


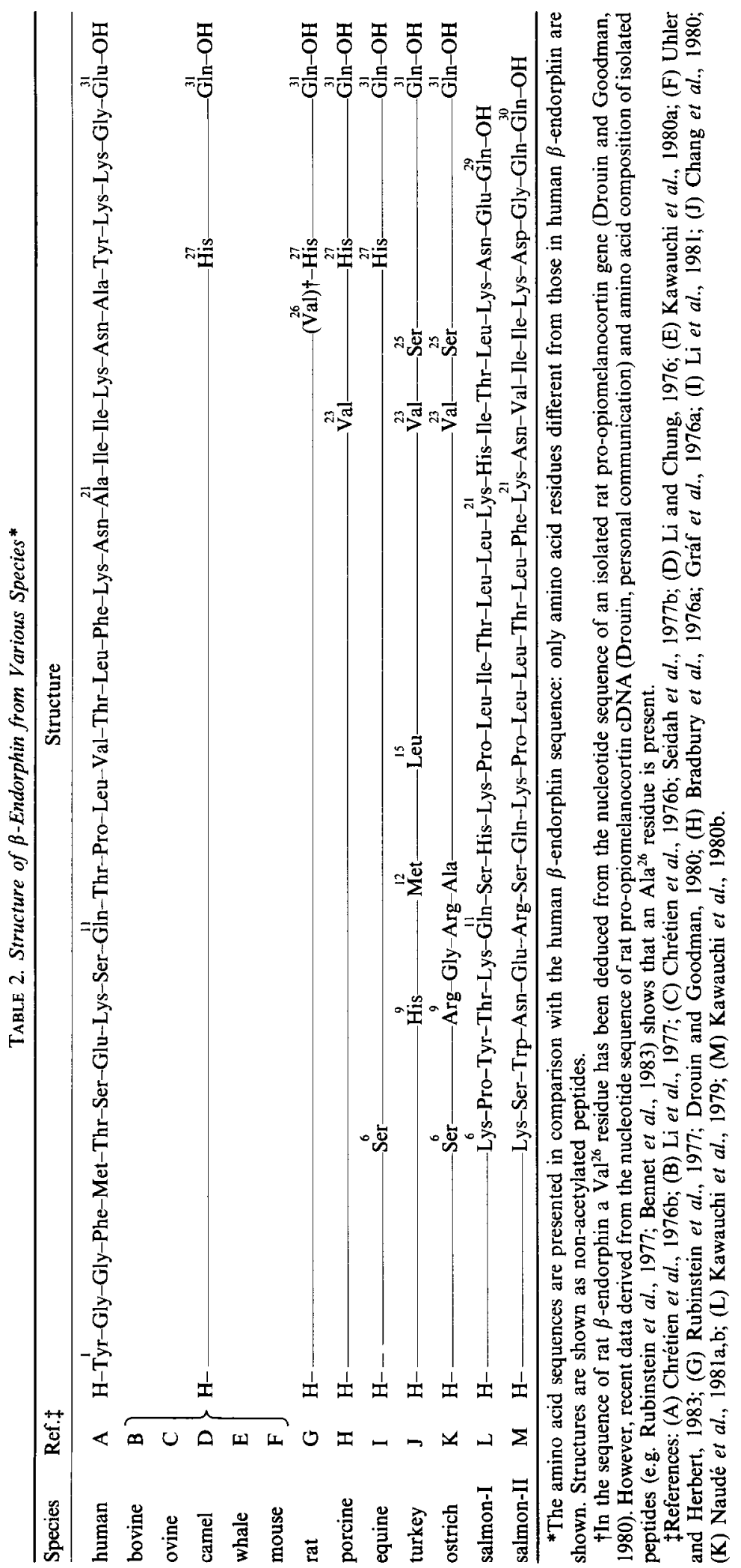


(Eipper and Mains, 1981; Evans et al., 1981; Smyth et al., 1982; Zakarian and Smyth, 1982a,b; Bennett et al., 1983). Consequently, at least six forms of $\beta$-endorphin exist, i.e. acetylated and nonacetylated $\beta$-endorphin-(1-31), $-(1-27)$ and $-(1-26)$.

In the intermediate lobe of the pituitary the predominant forms are the acetylated, truncated forms $N^{\alpha}$-acetyl- $\beta$-endorphin-(1-31), $\quad N^{\alpha}$-acetyl- $\beta$-endorphin-(1-27) and $N^{\alpha}$-acetyl- $\beta$-endorphin-(1-26), due to the processing pathway which involves a more rapid acetylation than proteolytic cleavage (Eipper and Mains, 1981; Glembotski, 1982a; Liotta et al., 1981; Zakarian and Smyth, 1982a,b). In the anterior lobe acetylation and proteolytic trimming does not take place and $\beta$-endorphin-(1-31) is the predominantly occurring form (Mains and Eipper, 1981; Zakarian and Smyth, 1982a,b; Smyth and Zakarian, 1982).

In brain a more complex profile of multiple forms of $\beta$-endorphin is obtained. In the hypothalamus which contains the pro-opiomelanocortin neuronal cell bodies proteolytic processing but virtually no acetylation occurs; predominant forms are $\beta$-endorphin-(1-31) and -(1-27) (Zakarian and Smyth, 1982a,b; Weber et al., 1981; Ng et al., 1982). Acetylation of $\beta$-endorphin seems to take place in extrahypothalamic areas containing terminals of the pro-opiomelanocortin neurons, in particular hippocampus, septum, colliculae, amygdala and brainstem (Zakarian and Smyth, 1979; Zakarian and Smyth, 1982a,b, Wiegant et al., 1983a). Other regions are rich in both acetylated and non-acetylated forms, like the thalamus and midbrain. Thus, two different sets of modified $\beta$-endorphins are found in different brain regions. It has been proposed that they represent two different processing pathways of $\beta$-endorphin in the brain (Zakarian and Smyth, 1982a,b): one mainly producing the opiate active form $\beta$-endorphin-(1-31), the other producing the $N^{\alpha}$-acetylated optiate inactive forms. These peptides, however, may still possess other central activities. For instance, the opiate inactive $\beta$-endorphin fragment $N^{\alpha}$-acetyl- $\gamma$-endorphin is fully active in behavioural paradigms (Wiegant $e t$ al., 1983a).

\subsection{2. $\beta$-Endorphin Fragments: $\alpha$ - and $\gamma$-Endorphins}

Two peptides being the $1-16$ and $1-17$ sequence of $\beta$-endorphin were initially identified from ovine hypothalamic-hypophyseal extracts by the group of Guillemin (Guillemin $e t$

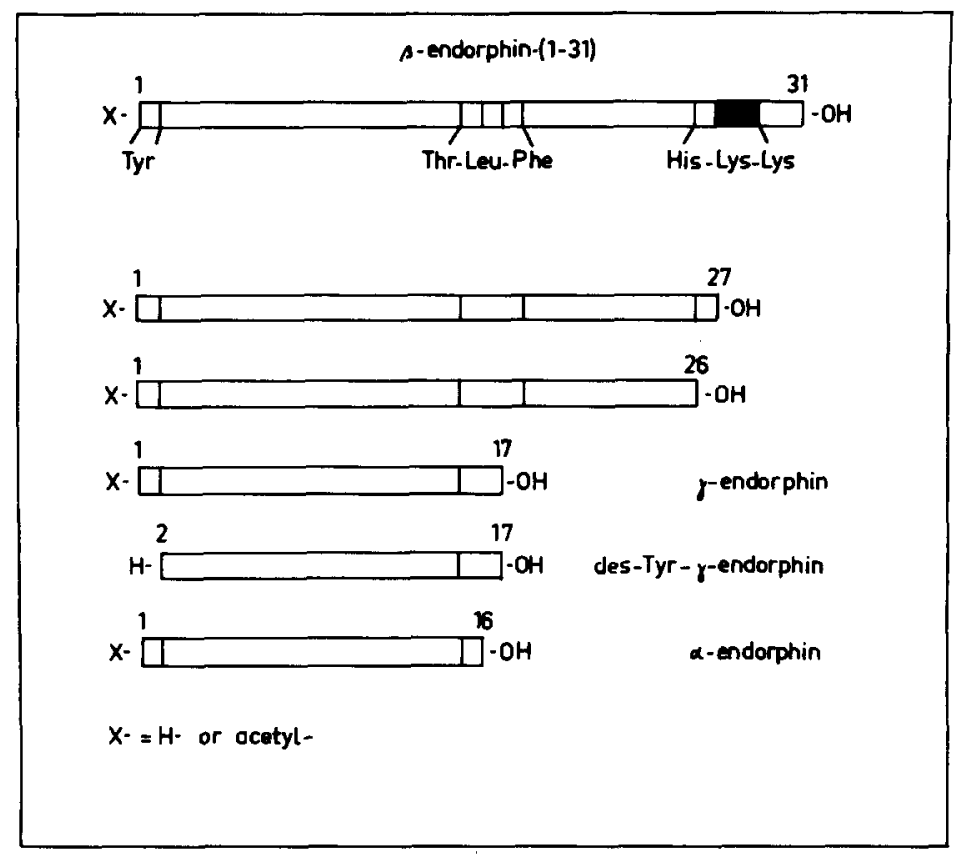

FIG. 3. $\beta$-Endorphin and derived peptides. Amino acid sequences of portions where proteolysis takes place are shown. These sequences are representative for most mammalian species, except human. Human $\beta$-endorphin has a $\mathrm{Tyr}^{26}$ residue (see Table 2); as a consequence the peptide $\beta$-endorphin-(1-26) does not occur in human tissues. 
al., 1976; Ling et al., 1976). These peptides have been designated $\alpha$-endorphin ( $\beta$-endorphin-(1-16)) and $\gamma$-endorphin ( $\beta$-endorphin-(1-17)) (Fig. 3). Subsequently, several reports have indicated indirectly the presence of $\alpha$ - and $\gamma$-endorphins in pituitary tissue by detecting peptides with opiate-like properties of the size of these $\beta$-endorphin fragments (Giagnoni et al., 1977; Sabol, 1978; 1980; Lissitsky et al., 1978). Peptides related to $\alpha$ - and $\gamma$-endorphin have been immunologically and/or chromatographically characterized in extracts of rat anterior and intermediate pituitary (Jegou et al., 1978, 1979; Fukata et al., 1979; Verhoef et al., 1980a,b, 1982; Dorsa et al., 1982; Wiegant et al., 1983a,b), in rat brain (Verhoef et al., 1980, 1982a,b; Dorsa et al., 1981; Wiegant et al., 1983a,b), in human pituitary and brain (Burbach and Wiegant, 1983; Wiegant et al., unpublished observations), in guinea pig myenteric plexus (Opmeer et al., 1980), and in rat testicular tissue (Tsong et al., 1982; Shu-Dong et al., 1982; Margioris et al., 1983). Immunohistochemical localization studies have shown the storage of $\alpha$-endorphin and $\gamma$-endorphins in pituitary and rat brain (Bégeot et al., 1978; Vaudry et al., 1980). Recently, $\alpha$-and $\gamma$-endorphins have been isolated from human pituitaries and chemically characterized (Burbach and Wiegant, 1983).

$N^{\alpha}$-Acetylated- $\alpha$ - and - $\gamma$-endorphins have been identified in the rat neurointermediate lobe and extrahypothalamic brain (Wiegant et al., 1983a,b; Sykes et al., 1983). The distribution of $\alpha$ - and $\gamma$-endorphins parallels that of $\beta$-endorphin although their levels are 5-10 fold lower (Verhoef et al., 1980; 1982a,b).

Formation of $\alpha$ - and $\gamma$-endorphins requires proteolytic cleavage in the $-\mathrm{Thr}^{16}$ $\mathrm{Leu}^{17}$-Phe ${ }^{18}$ sequence of $\beta$-endorphin. Such cleavage is distinctly different from the classical biosynthetic cleavage of paired basic amino acids which underly the formation of the $\mathrm{COOH}$-terminally truncated forms of $\beta$-endorphin, $\beta$-endorphin-(1-27) and $-(1-26)$ (Fig. 3). Proteolytic mechanisms able to form $\alpha$ - and $\gamma$-endorphins from $\beta$-endorphin have been indicated (see Section 4.1.).

In addition to $\alpha$-and $\gamma$-endorphins other $\beta$-endorphin fragments have been detected. Peptides with chromatographic properties of acetylated and non-acetylated $\beta$-endorphin-(1-21) have been detected in rat pituitary and brain tissue (Sykes et al., in preparation) and $\beta$-endorphin-(1-18) has been isolated from human autopsy pituitaries (Vuolteenako and Leppäluoto, 1983).

Important biological functions of $\alpha$ - and $\gamma$-endorphins have been discovered by de Wied and co-workers (de Wied, 1978; de Wied et al., 1980). It has been demonstrated that $\alpha$-endorphin and $\gamma$-endorphin each represent a separate class of neuropeptides with distinct behavioral activities (de Wied, 1978; Van Ree et al., 1980; Van Ree and de Wied, 1982; de Wied and Jolles, 1982). The behavioral effects of these peptides are independent from the opiate-like activities of $\alpha$ - and $\gamma$-endorphin. For example, $N^{\alpha}$-acetylated- $\gamma$-endorphin and fragments of $\gamma$-endorphin such as des-Tyr ${ }^{1}-\gamma$-endorphin ( $\beta$-endorphin- $(2-17)$ and $\beta$-endorphin-(6-17) which are devoid of opiate-like effects display full behavioral activities (de Wied, 1978; de Wied et al., 1978, 1980; Wiegant et al., 1983a). These data demonstrate the significance of $\alpha$ - and $\gamma$-endorphins as neuropeptides in the brain and point to a functional role of the proteolytic enzymes responsible for their formation (Burbach and de Wied, 1980, 1982; Burbach and de Kloet, 1982).

\section{ACTION OF PROTEOLYTIC ENZYMES ON $\beta$-LIPOTROPIN}

The structural relationship of $\beta$-lipotropin with $\gamma$-lipotropin, $\beta$-melanotropin and $\beta$-endorphin (Fig. 2) has prompted several investigators to indicate $\beta$-lipotropin as a precursor peptide (Chrétien and $\mathrm{Li}, 1967$; Bradbury et al., 1975, 1976a). Subsequent biosynthetic studies have supported this concept (Chrétien et al., 1976a, 1979; Herbert et al., 1980; Eipper and Mains, 1980). The primary function of $\beta$-lipotropin as precursor is also emphasized by the absence of an outspoken biological, e.g. hormonal, activity of $\beta$-lipotropin: although $\beta$-lipotropin possesses lipolytic activity on rabbit adipose tissue, it has very little lipolytic activity on rat and human fat cells (Chrétien and Lis, 1978; Lis, 1982). As a consequence of this precursor function of $\beta$-lipotropin studies on the 
proteolytic mechanisms underlying the processing of $\beta$-lipotropins into its endproducts have been undertaken. In particular two tissues have been subject to these studies. Firstly, the pituitary gland, which is most rich in $\beta$-lipotropin (anterior lobe) and its conversion products $\beta$-endorphins and $\gamma$-lipotropins (intermediate lobe) and secondly, the brain, in which the biological significance of the $\beta$-lipotropin conversion product $\beta$-endorphin as opioid neuropeptide is outspoken.

\subsection{Proteolysis of $\beta$-Lipotropin by Pituitary Enzymes}

\subsubsection{Processing Enzymes: Cleavage at Paired Basic Amino Acids}

Much experimental work has been focused on the formation of $\beta$-endorphin from $\beta$-lipotropin. It involves cleavage of peptide bonds of the paired basic amino acid residues in the (porcine) $\beta$-lipotropin sequence Asp ${ }^{58}$-Lys-Arg-Tyr ${ }^{61}$. Different approaches have been chosen to track down the proteolytic enzyme involved in this cleavage in the pituitary gland.

Bradbury et al. (1976a) using the synthetic hexapeptide H-Lys-Asp-Lys-Arg-Tyr-Gly$\mathrm{OH}$, observed that the Arg-Tyr bond was rapidly cleaved by an enzyme activity isolated from secretory granules of the pituitary. This proteolytic activity had a molecular weight of approximately 100,000 dalton and had a $\mathrm{pH}$ optimum of 8.5 . It was not inhibited by soya bean trypsin inhibitor, but was inactivated by phenylmethylsulphonyl fluoride. These properties distinguish the pituitary enzyme from pancreatic trypsin (Bradbury et al., 1976a; Austen and Smyth, 1978; Smyth et al., 1978).

At the same time Gráf and co-workers observed that by exposing porcine $\beta$-lipotropin to a pituitary homogenate $\beta$-lipotropin-(1-60) was formed (Gráf and Kenesey, 1976; Gráf et al., 1977). Other products present in the digests were $\beta$-lipotropin-(1-46) and -(1-79). In parallel with the formation of $\beta$-lipotropin-(1-60) peptides with opiate activity in the mouse vas deferens and guinea pig ileum bioassays were generated. The potency ratio's in these bioassays, however, indicated that the peptide was not $\beta$-endorphin-(1-31), but rather a shorter peptide like $\beta$-endorphin-(1-9) (Gráf et al., 1977). The proteolytic activity generating $\beta$-lipotropin-(1-60) was diminished in anterior pituitary homogenates of animals treated with dexamethasone or ACTH and was increased in the pituitary of adrenalectomized animals. The activity of the enzyme could also be determined by employing the synthetic substrate Z-Lys-Pro-Arg- $p$-nitroanilide and showed similar changes after experimental manipulation (Kenessey et al., 1979; Gráf et al., 1978a,b).

Further studies of Gráf and coworkers on the proteolytic activity responsible for $\beta$-endorphin formation has involved subcellular fractionation studies and partial purification of the enzyme from porcine anterior pituitaries (Kenessey et al., 1978; Gráf and Kenessey, 1981). The enzyme activity generating $\beta$-lipotropin-(1-60) co-purified with small and large secretory granule fractions (Kenessey et al., 1978). These subcellular fractions of anterior pituitary were similarly enriched in enzyme activity cleaving the synthetic substrate Z-Lys-Pro-Arg- $p$-nitroanilide. During subcellular fractionation the $\mathrm{Leu}^{77}-\mathrm{Phe}^{78}$ cleaving activity was dissociated from the $\mathrm{Arg}^{60}-\mathrm{Tyr}^{61}$ cleaving enzyme (Gráf et al., 1978a). The processing enzyme activity remained associated with secretory granule membranes after repeated freezing and thawing and Triton-X-100 treatment. However, after prolonged incubation of granule fractions at $37^{\circ} \mathrm{C}, \mathrm{pH} 8$, considerable activity was released. Further purification of solubilized enzyme activity involved ammonium sulfate precipitation and gel filtration, or affinity chromatography on immobilized Kunitz trypsin inhibitor (Gráf et al., 1979a; Gráf and Kenessey, 1981). A purification of at least 25 times was achieved. Further detailed biochemical studies on the enzyme activity were hampered by the extreme instability of the enzyme (Gráf and Kenessey, 1981).

Austen (1982) using the synthetic substrate Ac-Arg-Arg-naphthylamide, purified a serine protease-like enzyme from porcine anterior pituitaries that released $\beta$-endorphin from $\beta$-lipotropin. The enzyme had a molecular weight of 60,000 dalton and a $\mathrm{pH}$ optimum of 8-8.5. Other observations of processing enzymes with basic $\mathrm{pH}$ optima in the pituitary 
have been made by Lee and Lee (1982) using [ $\left.{ }^{125} \mathrm{I}\right]$ pro-opiomelanocortin and H-Arg-Leu$\mathrm{OH}$ and by Heinrich and Todd (1979) using pro-insulin as substrate. Using adrenal enkephalin precursors as substrate, Lindberg et al. (1982a,b) found similar proteolytic activity in adrenal chromaffin granules. These basic enzyme activities may be members of the kallikreins, a group of serine proteases with regulatory action (Schachter, 1980). Indeed, a recent report demonstrated the presence of a kininogenase resembling glandular kallikrein in the rat pars intermedia (Powers and Nasjletti, 1983). The pH optimum of 8 , the resistance of soya bean trypsin inhibitor and subcellular distribution indicate similarity of this kallikrein with activities described by Gráf and Austen.

In other studies biosynthetically labeled pro-opiomelanocortin has been employed to define processing enzyme activity with apparently different properties (Loh and Chang, 1982). Loh and co-workers recognized an enzyme activity which met the criteria for processing enzymes such as production of $\beta$-lipotropin, a $\beta$-endorphin-like peptide, a large form of ACTH and $\alpha$-MSH (Loh and Chang, 1982; Loh and Gainer, 1982a; Chang et al., 1982; Loh et al., 1982). The activity was detected in purified secretory granule fractions of rat and bovine neurointermediate lobes (Loh and Chang, 1982; Chang et al., 1982) and rat anterior lobe (Chang and Loh, 1983). The processing enzyme activity has been characterized by the use of inhibitors as an acid thiol, arginyl endopeptidase with a $\mathrm{pH}$ optimum of approximately pH 5 (Loh and Gainer, 1982a; Chang et al., 1982). This is close to the internal pH of 5.5 in secretory granules (Johnson and Scarpa, 1976; Russel and Holz, 1981).

This enzyme activity may be related or similar to other processing enzymes with acidic $\mathrm{pH}$ optima identified in pancreatic islet secretory granules of angler fish and rat pancreas (Fletcher et al., 1980, 1981; Docherty et al., 1982; 1983) and adrenal chromaffin granules (Mizuno et al., 1982; Evangelista et al., 1982; Troy and Musacchio, 1982). These enzymes have been defined on the basis of cleavage of pro-insulin, pro-glucagon, pro-somatostatin and/or enkephalin precursors. Several of these enzyme activities have been identified as cathepsin B (MacGregor et al., 1979a,b; Docherty et al., 1983). Properties of processing enzymes are listed in Table 3.

It has not been established as yet which of the two kinds of processing enzymes is physiologically involved in precursor processing or whether both have separate functions. The two types of enzymes differ markedly (Table 3), but fulfill several criteria for processing enzymes. However, the studies which describe purification and properties of the enzymes differ in tissue, species, substrates, assay conditions, and approach of purification. These aspects have recently been reviewed (Docherty and Steiner, 1982; Lazure et al., 1983).

\subsubsection{Chymotryptic-Like Enzymes}

Seidah et al. (1983) recently described properties of an enzyme activity from a pig anterior pituitary secretory granule lysate. The enzyme had specificity towards some $P h e-X$ and Tyr-X bonds in rat pro-opiomelanocortin, suggesting similarity with chymotrypsin. In the $\beta$-lipotropin region of pro-opiomelanocortin it cleaved the $\mathrm{Phe}^{168}-\mathrm{Arg}^{169}$ (rat $\beta$-lipotropin-(30-31)) bond. The $\mathrm{pH}$ optimum was 8 . Chymotryptic-like activity has been reported to be present in anterior pituitary tissue previously (Horsthemke and Bauer, 1981). Noteworthy, enzymes with chymotryptic-like specificities have been implicated in the processing of several hormones including gastric inhibitory polypeptide, relaxin, pro-insulin and the $\mathrm{COOH}$-terminal glycopeptide of the vasopressin precursors (Docherty and Steiner, 1982; Jörnvall et al., 1981; Hudson et al., 1981; Tager et al., 1973; Smyth and Massey, 1979, Land et al., 1982).

\subsubsection{Cathepsin D}

The observation of Gráf and Kenessey (1976) that digestion of porcine $\beta$-lipotropin by anterior pituitary homogenates at $\mathrm{pH} 6.5$ resulted predominantly in cleavage of the 


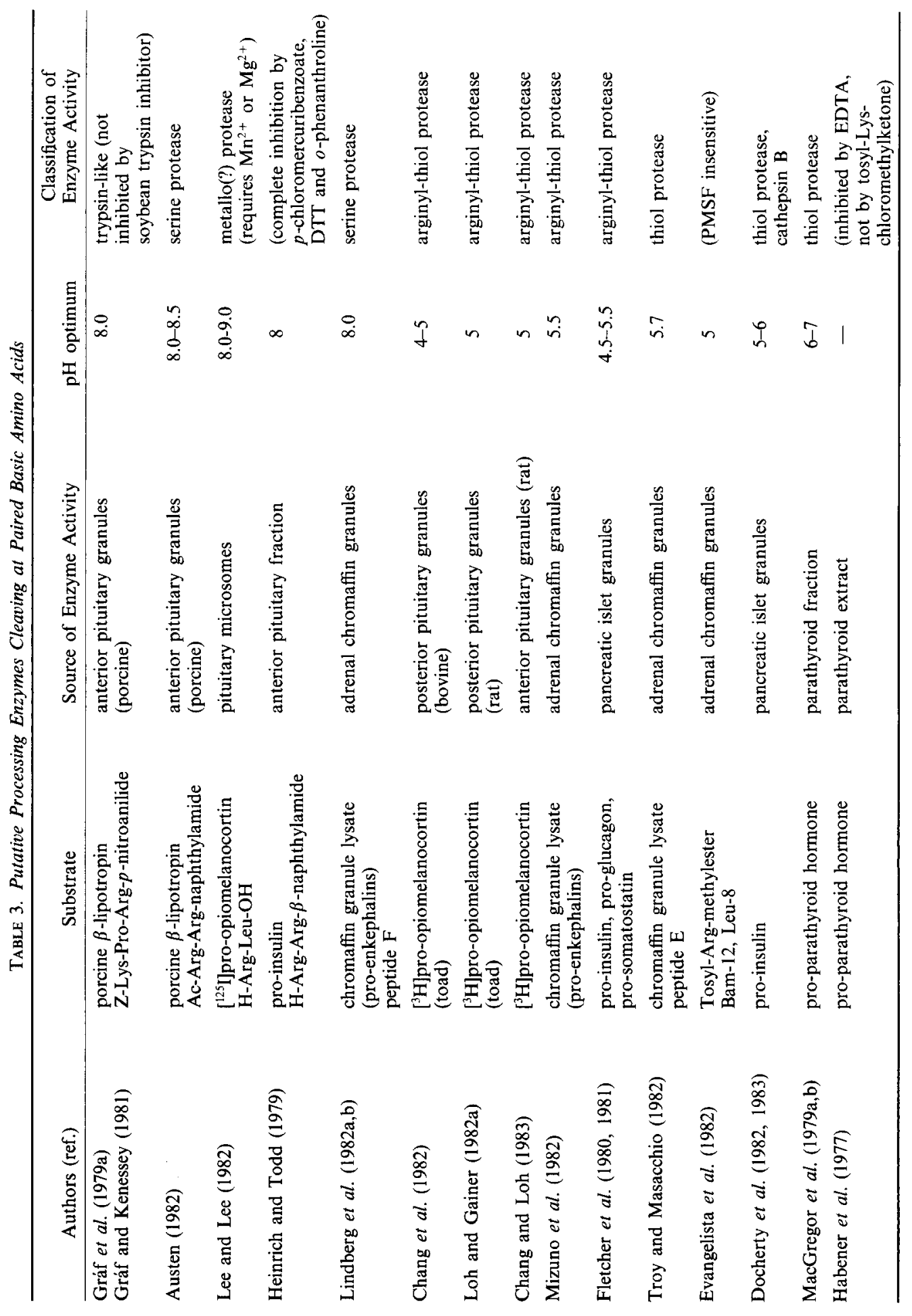


$\mathrm{Leu}^{77}-\mathrm{Phe}^{78}$ bond, thus in formation of $\beta$-lipotropin-(1-77), has prompted further studies on the proteolytic enzyme involved. The $\mathrm{pH}$ optimum of approximately 4 , the inhibition by $10^{-6} \mathrm{M}$ pepstatin, which is a carboxyl-proteinase inhibitor (Umezawa and Aoyagi, 1977), and its subcellular localization suggested that the enzyme activity might be lysosomal cathepsin D (Gráf et al., 1978a, 1979a). Indeed, cathepsin D purified from human pituitaries cleaved $\beta$-lipotropin into a product co-migrating with $\beta$-lipotropin-(1-77) (Benuck et al., 1978b) (see Section 3.3.1).

\subsection{Proteolysis of $\beta$-Lipotropin by Brain Enzymes}

The proteolytic conversion of $\beta$-lipotropin by enzymes in brain tissue has been investigated in order to define the processes responsible for the production of the opioid peptide $\beta$-endorphin. Kenessey et al. (1977) investigated the proteolysis of porcine $\beta$-lipotropin by brain homogenates at $\mathrm{pH} 6.5$ and $\mathrm{pH} 8.0$. The predominant product formed at $\mathrm{pH} 6.5$ had electrophoretic properties of $\beta$-lipotropin-(1-77). No regional differences in the profiles of products were observed in brain. The electrophoretic pattern was similar as the one produced by homogenates of pituitary pars distalis, pars intermedia and pars nervosa. The cleavage of $\beta$-lipotropin was stimulated by dithiothreitol and Versene (Kenessey et al., 1977). Further work of this group confirmed these data at $\mathrm{pH}$ 4.0 and demonstrated that the formation of $\beta$-lipotropin-(1-77) by brain homogenates was due to cathepsin D activity (Gráf et al., 1979a). Cathepsin D isolated from bovine brain by affinity chromatography (Benuck et al., 1978a) cleaved the Leu-Phe bond of porcine and human $\beta$-lipotropin (Benuck et al., 1978b; Gráf et al., 1979b; Barát et al., 1979). At $\mathrm{pH} 8$ porcine $\beta$-lipotropin was degraded only very slowly by brain homogenates. No degradation products have been identified under these conditions. However, at pH 8 in the presence of bacitracin opiate activity was generated during incubation of $\beta$-lipotropin with a mitochondrial-synaptosomal (P2) fraction of rat brain as tested on the mouse vas deference preparation (Gráf et al., 1979a) indicating that the $\mathrm{Arg}^{60}-\mathrm{Tyr}^{61}$ bond of porcine $\beta$-lipotropin was cleaved. However, accumulation of opiate activity was much less than of an analogous fraction of the pituitary.

Austen and Smyth (1978) found in brain only low enzyme activity cleaving the synthetic substrate H-Lys-Asp-Arg-Tyr-Gly-OH (porcine $\beta$-lipotropin-(57-62)) between Arg and Tyr. The enzyme activity was most concentrated in the pituitary gland.

\subsection{ACtion of Purified EnZymes on $\beta$-Lipotropin}

\subsubsection{Cathepsin D}

Above mentioned action of cathepsin D on $\beta$-lipotropin (see Section 3.1.3) has been investigated in more detail by using the purified enzyme. Cathepsin D purified from calf brain by affinity chromatography on pepstatin-Sepharose (Benuck et al., 1978a) split initially the Leu-Phe bond of human (residues 75-76) and porcine $\beta$-lipotropin (residues 77-78), forming $\beta$-lipotropin-(1-75) and -(1-77) respectively, and $\beta$-endorphin-(18-31) (Gráf et al., 1979b; Barát et al., 1979). During longer incubation of porcine $\beta$-lipotropin the $\mathrm{Ala}^{32}-\mathrm{Glu}^{33}$ peptide bond was cleaved as well by the enzyme preparation. The secondary cleavage site in human $\beta$-lipotropin was the $\mathrm{Ala}^{34}-\mathrm{Ala}^{35}$ bond (Barát et al., 1979) (Fig. 2). This cleavage could be responsible for artifactual formation of human $\beta$-melanotropin. Based on these data Barát et al., (1979) pointed to a peculiar specificity of cathepsin $\mathrm{D}$, which rather seems to have a preference for the hydrophobic residues Leu-Val at positions 2 or 3 before the cleavage site than for the amino acids forming the cleaved bond. This suggestion is supported by observations of Lebouille and Burbach (unpublished) that the action of cathepsin D purified from bovine spleen on small synthetic peptides derived from $\beta$-endorphin is prevented when the Leu-Val sequence is modified (Table 4).

In contrast to above mentioned studies seven to eight cleavage sites in porcine $\beta$-lipotropin have been reported by Akopyan and colleagues who used a cathepsin D 


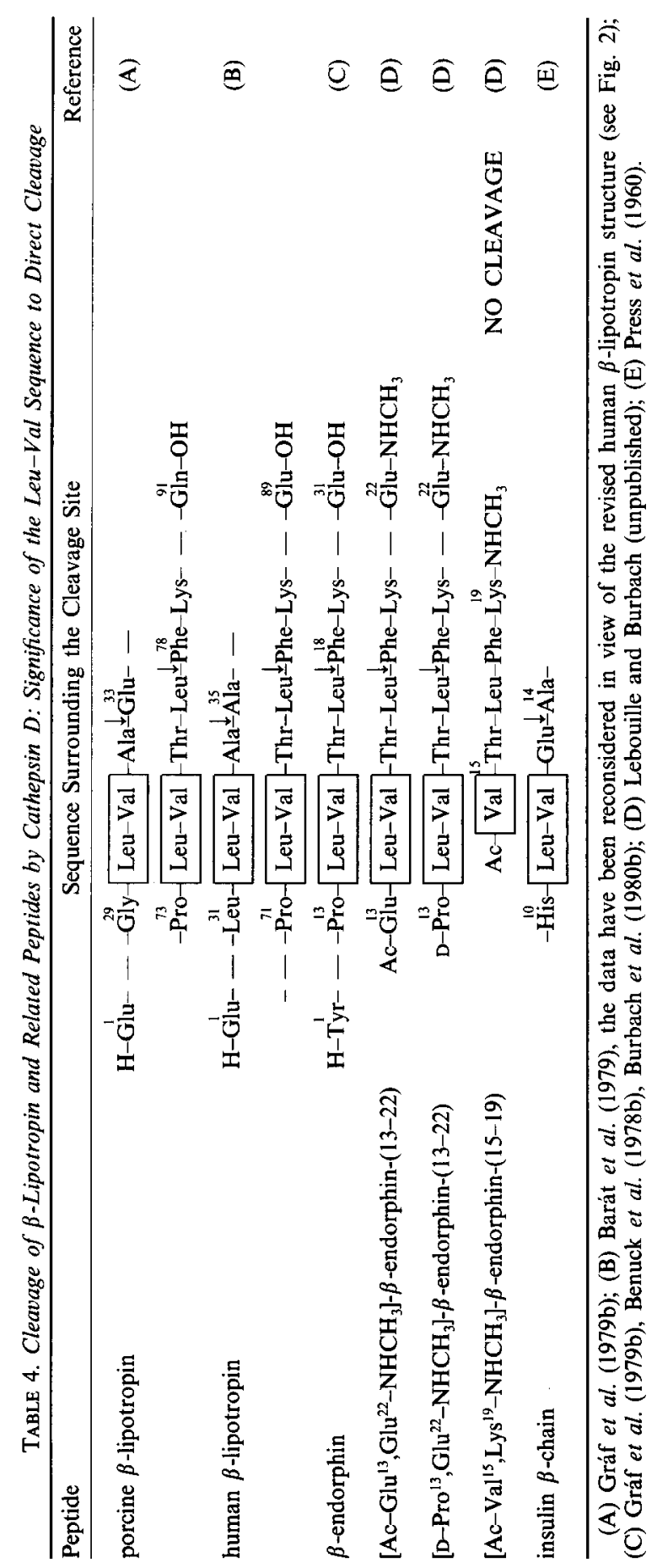


preparation from bovine hypothalamus (Arytyunyan et al., 1980, 1981; Akopyan et al., 1982). These sites include the 14-15, 25-26, 26-27, 29-30, 31-32, 49-50, 63-64 and 77-78 peptide bonds of porcine $\beta$-lipotropin (for structure see references in Table 1). These results differ from those of Gráf et al., (1979b) and Barát et al., (1979) who found only two cleavage sites. Differences may be due to the purity of the cathepsin D preparations and/or the incubation conditions used.

\subsubsection{Plasmin}

Studies on the fragmentation of porcine $\beta$-lipotropin by plasmin showed that the Lys $^{79}-\mathrm{Asn}^{80}$ bond was most susceptible to the enzyme; the fragment $\beta$-lipotropin-(1-79) appeared as initial product (Gráf, 1976). Secondary cleavage sites were the $\operatorname{Arg}^{51}-\operatorname{Trp}^{52}$ and $\mathrm{Arg}^{60}-\mathrm{Tyr}^{61}$ peptide bonds. The $\mathrm{Lys}^{46}-\mathrm{Met}^{47}, \mathrm{Lys}^{69}-\mathrm{Ser}^{70}$ and $\mathrm{Lys}^{84}-\mathrm{Asn}^{85}$ bonds were hydrolyzed only very slowly. Further lysyl and arginyl bonds of porcine $\beta$-lipotropin were not cleaved under the experimental conditions (Gráf, 1976; Gráf and Li, 1973). Although plasmin displayed some preference for hydrophobic residues in the surrounding region of the cleavage site adjacent to lysyl or arginyl residues, no clear-cut preference for particular residues was obtained, possibly due to conformational properties of $\beta$-lipotropin.

\subsubsection{Trypsin}

The influence of $\beta$-lipotropin conformation on proteolytic enzyme action has been studied using immobilized trypsin (Gráf and Hollósi, 1980). Mild digestion of porcine $\beta$-lipotropin by trypsin-Sepharose in aqueous solution resulted in cleavage of the $\operatorname{Arg}^{51}-\operatorname{Trp}^{52}$ and $\operatorname{Arg}^{60}-\operatorname{Tyr}^{61}$ bonds. In $20 \%$ trifluoroethanol, a secondary structure promoting solvent, the $\mathrm{Arg}^{60}-\mathrm{Tyr}^{61}$ bond was exclusively split. The $\mathrm{Arg}^{51}-\mathrm{Trp}^{52}$ sequence lies in a region with high $\alpha$-helix potential and may therefore have a more rigid conformation as compared to the $\mathrm{Arg}^{60}-\mathrm{Tyr}^{61}$ sequence which may be sterically exposed for enzyme attack since it is neighboured by two $\beta$-turns (Gráf and Hollósi, 1980). These data have been considered as support for the views of Geisow (1978) and Loh and Gainer $(1978,1979)$ that specificity of proteolytic processing is partly directed by the conformation of the substrate. However, later work of Loh and Gainer (1982b) seem to contradict this view, since it was shown that glycosylated and non-glycosylated pro-opiomelanocortin was qualitatively and quantitatively similarly processed by a pro-opiomelanocortin converting enzyme activity.

Trypsin has also been used to prepare authentic opiate-active $\beta$-endorphin from citraconylated $\beta$-lipotropin (Seidah et al., 1977a; Geisow and Smyth, 1977b).

\subsubsection{Tonin}

Tonin, a serine protease converting angiotensinogen directly into angiotensin II, occurs in high concentrations in the submaxillary gland, and is also present in the pituitary (Boucher et al., 1974; Demassieux et al., 1976; Seidah et al., 1979). At pH 6.8 ovine $\beta$-lipotropin was split by tonin purified from rat submaxillary glands between residues 50-51, 51-52, 60-61 and 78-79 (Seidah et al., 1979). At pH 5.0 main cleavage sites were 23-24, 51-52, 60-61, 78-79 and 79-80 (Chan et al., 1981). Amongst fragments released during digestion were $\beta$-lipotropin-(61-78), $-(61-79)$ and $-(61-91)$, which all possess opioid properties. Optimal accumulation of opioid activity was reached by prolonged tonin digestion at $\mathrm{pH} 5.0$ (Chan et al., 1981). Using the release of opioid activity after tonin digestion, an assay to detect $\beta$-lipotropin was constructed (Chan et al., 1981).

\subsubsection{Cathepsin B}

Cathepsin B purified from calf brain has been shown to split $\beta$-lipotropin into several products (Suhar and Marks, 1979; Marks et al., 1980). The products and cleavage sites have not been determined, however. 


\section{ACTION OF PROTEOLYTIC ENZYMES ON $\beta$-ENDORPHIN}

$\beta$-Endorphin is a product of the intracellular processing of pro-opiomelanocortin in the pituitary gland (Crine et al., 1979; Mains and Eipper, 1979; Roberts et al., 1978) as well as in the brain (Liotta et al., 1980; Gramsch et al., 1980). The potent opioid properties of $\beta$-endorphin indicated an important physiological function of the peptide in the central nervous system (Bradbury et al., 1976b; Cox et al., 1976; Li and Chung, 1976; Loh et al., 1976; Van Ree et al., 1976; Seidah et al., 1977). Consequently, most studies on the proteolysis of $\beta$-endorphin have been concerned with brain tissue. Many of them were carried out from the viewpoint of inactivation of opioid activity or mere degradation of $\beta$-endorphin. Others, however, have considered proteolytic cleavage of $\beta$-endorphin as a process necessary for formation of peptides with biological function.

Firstly, these studies have focused on $\alpha$ - and $\gamma$-endorphins. The $\beta$-endorphin fragments $\alpha$ - and $\gamma$-endorphins and their $N^{\alpha}$-acetylated forms are endogenous peptides in the pituitary and the brain and they possess separate biological activities indicating a function of $\beta$-endorphin as precursor peptide (see Section 2.2.2.). The biotransformation of $\beta$-endorphin into these peptides has been investigated.

Secondly, prompted by the identification of the enkephalins by Hughes et al. (1975), $\beta$-endorphin has initially been considered as precursor or biosynthetic intermediate of methionine-enkephalin. A few reports deal with enzyme activities able to release the methionine-enkephalin sequence $(\beta$-endorphin-(1-5)) from $\beta$-endorphin. Later research, however, has clearly demonstrated that methionine-enkephalin is not derived from $\beta$-endorphin and that a separate precursor for methionine-enkephalin exists (Comb et al., 1982; Gubler et al., 1982; Legon et al., 1982; Noda et al., 1982a,b).

\subsection{Proteolysis of $\beta$-Endorphin in Brain Tissue}

\subsubsection{Homogenates and Soluble Fractions}

$\beta$-Endorphin is rapidly degraded by proteolytic enzymes present in homogenates and soluble fractions of brain tissue. This process has mainly been investigated by following the release of amino acids during exposure of $\beta$-endorphin to soluble fractions of brain tissue. Marks et al., (1977) observed that after 5 min of incubation at $\mathrm{pH} 7.63$ to $7 \%$ of several amino acid residues from different positions of the $\beta$-endorphin sequence appeared, while other amino acids were absent. However, after $30 \mathrm{~min}, 60 \mathrm{~min}$ and $180 \mathrm{~min}$ of incubation (Marks et al., 1977; Marks et al., 1978; Marks, 1978) all amino acid residues were detected in approximately equal amounts, with some preference for tyrosin, methionine, glutamine and leucine (for the primary structure of $\beta$-endorphin see Table 2 ). Using a similar approach Patthy et al. (1977) also observed a time dependent release of all the constituent amino acids, proportionally to the data reported by Marks et al. (1977) except for methionine which was considerably lower in the experiment of Patthy and co-workers and phenylalanine and lysine which were released more rapidly. These studies indicated: (1) that initially a limited number of peptide bonds are cleaved and (2) that multiple types of enzyme activities cleaving the $\beta$-endorphin sequence at different sites are involved in the degradation. The authors suggested the action of trypsin-like enzyme activity.

The preferential release of lysine, leucine and phenylalanine suggested peptidase action on the mid position of $\beta$-endorphin, which was in accord with earlier findings of Gráf and co-workers (Gráf and Kenessey, 1976; Kenessey et al., 1977) of an enzyme activity cleaving the $\mathrm{Leu}^{17}-\mathrm{Phe}^{18}$ bond of $\beta$-endorphin. The high degree of release of tyrosine from the $\mathrm{NH}_{2}$-terminus of $\beta$-endorphin indicated the presence of aminopeptidase activities.

Additional studies with peptidase inhibitors and D-amino acid substituted analogs provided more insight in the mechanism of proteolysis of $\beta$-endorphin by brain soluble enzymes. The inhibition of tyrosine release by bacitracin, an antibiotic peptidase inhibitor (Desbuquois et al., 1974), provided more evidence for the involvement of aminopeptidases (Patthy et al., 1977). Moreover it appeared that also the release of phenylalanine, leucine, 
isoleucine and valine was markedly inhibited by bacitracin which led the authors to suggest that also brain carboxypeptidases were inhibited by bacitracin. Indeed, it was observed that bacitracin not only effectively protects $\beta$-endorphin fragments against aminopeptidase degradation, but it also inhibits carboxypeptidases as well as endopeptidases in a rather non-specific fashion (Burbach, unpublished). The effect of bacitracin in the presence of Boc-D-Phe-Pro-Arg-OH, a selective serine protease inhibitor (Bajusz et al., 1975, 1978), was even more outspoken (Gráf et al., 1979a) and showed the different inhibitory mechanisms of these compounds. Pepstatin, an inhibitor of carboxyl proteases such as cathepsin D (Umezawa and Aoyagi, 1977), had only a minor effect. The most significant effect of inhibition of $\beta$-endorphin degradation by pepstatin was the slower release of leucine and phenylalanine, which is in agreement with cleavage of the Leu ${ }^{17}-\mathrm{Phe}^{18}$ bond by cathepsin D (Benuck et al., 1978b; Gráf et al., 1979b, see also Section 4.1.3).

Marks et al. (Marks et al., 1978; Grynbaum et al., 1977) provided additional arguments for the action of exo- and endopeptidase activities on $\beta$-endorphin by studying the degradation of $\beta$-endorphin analogs. The replacement of glycine ${ }^{2}$ by $D$-alanine significantly reduced $\mathrm{NH}_{2}$-terminal breakdown as reflected by the relatively low release of tyrosine (Grynbaum et al., 1977). The yields of all amino acids released from [D-Ala $\left.{ }^{2}\right]-\beta$-endorphin was reduced as compared to $\beta$-endorphin, indicating that the substitution also affected other cleavage sites in the peptide. Incubation of the $\left[D-\mathrm{Leu}^{17}, \mathrm{D}-\mathrm{Lys}{ }^{19}\right]$-analog of $\beta$-endorphin with a mouse brain extract led to rapid release of tyrosine and relatively rapid release of alanine and isoleucine. The overall degradation of the analog was slower than that of native $\beta$-endorphin (Marks et al., 1978). The triple substituted analog [D-Thr ${ }^{6}$, $\left.\mathrm{D}-\mathrm{Leu}^{17}, \mathrm{D}-\mathrm{Lys}^{19}{ }^{19}\right]-\beta$-endorphin was even more resistant to degradation by soluble peptidases. Again the release of tyrosine, isoleucine, and alanine was predominant.

These experiments, based on the release of free amino acids indicated the involvement of a number of different peptidases in the proteolysis. Firstly, aminopeptidases released rapidly the $\mathrm{NH}_{2}$-terminal tyrosine, but were less active in removing the contiguous glycine residues. However, tyrosine release seemed to be preceded by internal bond cleavages (Gráf et al., 1979a). Secondly, endopeptidases cleaved $\beta$-endorphin at different sites, primarily in the midportion of the peptide around residues 15 to 22 . Thirdly, a role for carboxypeptidases in the degradation of initially formed $\beta$-endorphin fragments was also suggested (Patthy et al., 1977). Indeed, the COOH-terminal amino acids of [D-Ala $\left.{ }^{2}\right]-\gamma$-endorphin and $\left[\mathrm{D}-\mathrm{Ala}^{2}\right]-\alpha$-endorphin were rapidly released upon incubation with mouse brain extracts (Grynbaum et al., 1977). The experimental approach, which is not suitable for identification of the products of proteolysis, did not enable one to define the precise cleavage sites nor the sequence of proteolytic events. In general, the observations made indicate that the mechanism of $\beta$-endorphin proteolysis by soluble fractions of brain is comparable with that by brain membrane associated peptidases (see Section 4.1.2).

Experiments aimed to identify the products of $\beta$-endorphin proteolysis by soluble peptidase are limited. Rossier et al. (1977) showed by radioimmunoassay that $\alpha$-endorphin was one of the intermediates in the proteolysis of $\beta$-endorphin by rat brain extracts. Under the conditions used $\beta$-endorphin had a half-life of $47 \mathrm{~min}$ and $\alpha$-endorphin represented approximately $5 \%$ of the initial amount of $\beta$-endorphin after $2 \mathrm{hr}$ of incubation. Palmour et al., (1978) incubated $\left[{ }^{125} \mathrm{I}\right]$-iodinated $\beta$-endorphin and $\left[\mathrm{Leu}{ }^{5}\right]-\beta$-endorphin with dialyzed supernatants from rat brain and compared radioactive products by thin-layer electrophoresis with standard peptides. A very rapid degradation of the $\beta$-endorphins was observed accompanied by the formation of free tyrosine as the main radioactive product. The half-life of $\beta$-endorphin was $12 \mathrm{~min}$ and that of $\left[\mathrm{Leu}^{5}\right]-\beta$-endorphin $9 \mathrm{~min}$. The main peptide fragments found were $\beta$-endorphin-(1-4) and $\left[\mathrm{Leu}^{5}\right]-\beta$-endorphin-(1-5). Small quantities of $\gamma$-endorphin were found. The production of peptides with chromatographic properties of $\alpha$ - and $\gamma$-endorphin by whole brain homogenates has been reported (Davies et al., 1982). Experiments of our group showed that rat brain cytosol converted $\beta$-endorphin into a number of peptides including $\alpha$ - and $\gamma$-endorphin as characterised by high-pressure liquid chromatography. Homogenates and various subcellular fractions including mitochondria, microsomes, synaptosomes and soluble fractions also generated 
$\alpha$ - and $\gamma$-endorphins, suggesting a broad cellular distribution of proteolytic enzymes able to produce these $\beta$-endorphin fragments (Burbach, unpublished).

Enzyme activities cleaving the $\mathrm{Met}^{5}-\mathrm{Thr}^{6}$ bond of $\beta$-endorphin, thus forming methionine-enkephalin, have been detected in brain soluble fractions (Aono et al., 1978; Koida et al., 1979; Austen et al., 1977a; Austen and Smyth, 1978; Knight and Klee, 1979; Palmour et al., 1978; Orlowski et al., 1980). Knight and Klee (1979) described properties of this enzyme activity, while others have purified enzymes cleaving the $\mathrm{Met}^{5}-\mathrm{Thr}^{6}$ bond (Koida et al., 1979; Orlowski et al., 1980). Initially these enzymes were thought to have a role in the biosynthesis of methionine-enkephalin. However, since the discovery of enkephalin biosynthetic pathways independent of $\beta$-endorphin, these enzymes have received little attention.

\subsubsection{Slice Preparations, Synaptosomes and Synaptic Membranes}

Experiments on the proteolysis of peptides employing homogenates and soluble extracts are likely to expose a bulk of degradative peptidases to the substrate which are not functionally involved in the conversion and degradation of the peptides under physiological conditions. In several studies on the proteolysis of endorphins, it has been attempted to restrict the interference of 'contaminating' peptidases by using brain slices, synaptosomal preparations or isolated synaptic membranes. The assumption that functional proteolytic events in the conversion or degradation of endorphins take place extracellularly, in or near the synaptic environment, the sites of storage, release and action of endorphins, underly the choice of these preparations. In addition, a push-pull perfusion technique has been employed to study the conversion of locally applied peptide in a restricted brain area (Burbach, 1983).

Smyth and Snell $(1977 \mathrm{a}, \mathrm{b})$ incubated $\left[{ }^{125} \mathrm{I}-\mathrm{Tyr}^{1}\right]-\beta$-endorphin or $\left[{ }^{125} \mathrm{I}-\mathrm{Tyr}^{1}\right]-\gamma$-endorphin with slices of the rat striatum. Under the experimental conditions $\left[{ }^{125} \mathrm{I}\right]-\beta$-endorphin had a half-life of $3.2 \mathrm{hr}$; the half-life of $\left[{ }^{125} \mathrm{I}\right]-\gamma$-endorphin was notably shorter, i.e. $1.1 \mathrm{hr}$. Bacitracin, a bacterial substance with aminopeptidase inhibiting properties (Desbuquois et al., 1974), did not affect the proteolysis of $\left[{ }^{125} \mathrm{I}\right]-\beta$-endorphin, but it increased the half-life of $\left[{ }^{125} \mathrm{I}\right]-\gamma$-endorphin to $3.6 \mathrm{hr}$. These results indicated firstly that the $\mathrm{NH}_{2}$-terminus of $\beta$-endorphin is markedly more resistant to proteolytic attack than $\gamma$-endorphin and secondly that cleavage of $\beta$-endorphin is not initiated by aminopeptidases, but by other types of peptidases presumably endopeptidases. Protecting the $\mathrm{NH}_{2}$-terminal $\left[{ }^{125} \mathrm{I}\right]$ tyrosine residue of products by including bacitracin in the incubation medium, Smyth and Snell $(1977 \mathrm{a}, \mathrm{b})$ demonstrated that the major product of conversion of $\left[{ }^{125} \mathrm{I}\right]-\beta$-endorphin was $\left[{ }^{125} \mathrm{I}\right]-\gamma$-endorphin. Low quantities of $\left[{ }^{125} \mathrm{I}\right]-\alpha$-endorphin, methionine-enkephalin, $\beta$-endorphin-(1-6), and $\beta$-endorphin-(1-7) were reported (Smyth and Snell, 1977b). These investigators pointed out that these products were formed extracellularly in the slice preparation. No active uptake of $\left.{ }^{125} \mathrm{I}\right]$ peptides by the tissue was observed.

Similar results were obtained when washed synaptosomes were used (Austen et al., 1977a,b; Austen and Smyth, 1977a,b; Smyth et al., 1977). At pH $7.4\left[{ }^{125} \mathrm{I}\right]-\beta$-endorphin was principally converted into $\left[{ }^{125} \mathrm{I}\right]-\gamma$-endorphin and there was a small amount of $\left[{ }^{125} \mathrm{I}\right]$-methionine-enkephalin. The accumulation of these peptides was strongly favoured by the presence of bacitracin or by acid $\mathrm{pH}$ due to inhibition of aminopeptidase activity. At $\mathrm{pH} 5.0$ the proteolysis was more rapid and the products characterized were $\left[{ }^{125} \mathrm{I}\right]-\alpha$-endorphin, $\left[{ }^{125} \mathrm{I}\right]-\beta$-endorphin-(1-13), $-(1-8)$ and $\left[{ }^{125} \mathrm{I}\right] \mathrm{methionine-enkephalin.} \mathrm{Aus-}$ ten et al. (1977; Austen and Smyth 1977a,b) also observed that synaptosomes contained an endopeptidase cleaving the peptide $\beta$-endorphin-(1-7) into methionine-enkephalin and the dipeptide Thr-Ser. This endopeptidase activity was associated with membranes, but did not co-purify with the membrane components carrying the opiate receptors. A similar endopeptidase activity has been found by Knight and Klee (1979) and by Koida and co-workers (Koida et al., 1979; Aono et al., 1978).

Main events in the proteolytic conversion of $\beta$-endorphin by brain synaptic membrane associated peptidases have been detected by chemical characterization of $\beta$-endorphin 
fragments which accumulated during incubation of $\beta$-endorphin-(1-31) with brain synaptic membrane preparations (Burbach et al., 1980a; 1981; Burbach and de Kloet, 1982). Incubation of $\beta$-endorphin under different $\mathrm{pH}$ conditions resulted in formation of $\beta$-endorphin-(1-21) and -(2-21), $\beta$-endorphin-(1-17) and -(2-17) together with -(18-31), and shorter $\mathrm{NH}_{2}$-terminal peptides as $\beta$-endorphin-(1-16), -(1-14), and -(1-13) (Burbach et al., 1980a, 1981; Burbach and de Kloet, 1982). In addition, a small amount of $\beta$-endorphin-(1-18) was detected (Burbach, 1980). From time course studies it appeared that $\beta$-endorphin-(1-17) and $-(1-21)$ were the initially formed products.

The proteolytic conversion of $\beta$-endorphin-(1-17) ( $\gamma$-endorphin) and $-(2-17)$ have been further investigated in detail. $\gamma$-Endorphin is susceptible to amino- and carboxy- and endopeptidases in brain synaptic membranes. At pH $6.7 \beta$-endorphin-(2-17), -(5-17), $-(6-17),-(7-17),-(8-17)$ and $-(1-16)$ are found, while at $\mathrm{pH} 5.0$ exclusively the carboxypeptidase products $\beta$-endorphin-(1-16), $-(1-15),-(1-14)$ and $-(1-13)$ are formed (Burbach et al., 1981). In view of its non-opioid, neuroleptic-like activities and its clinical application as antipsychotic neuropeptide (de Wied, 1978; de Wied et al., 1978; Verhoeven et al., 1979, 1981; Van Ree et al., 1983) studies have been concerned with the proteolytic cleavage of des-tyrosine- $\gamma$-endorphin ( $\beta$-endorphin-(2-17)). The main metabolites which accumulated during in vitro incubation of des-tyrosine- $\gamma$-endorphin with a synaptic membrane preparation, were isolated in two high-pressure liquid chromatography steps and chemically characterized (Burbach et al., 1980c). Two sets of fragments were identified. Firstly the $\mathrm{COOH}$-terminally truncated fragments $\beta$-endorphin-(2-16), $-(2-14)$ and $-(2-13)$ were found; $\beta$-endorphin-(2-13) was present in highest amounts. Secondly, peptides with intact $\mathrm{COOH}$-terminus were formed in vitro by exposure of des-tyrosine- $\gamma$-endorphin with synaptic membranes. They included $\beta$-endorphin-(5-17), -(6-17), - (7-17) and -(8-17). The major products were $\beta$-endorphin-(5-17) and $-(6-17)$. The time dependency of their formation indicated that $\beta$-endorphin-(5-17) was initially formed, while $\beta$-endorphin(6-17) appeared later. Possibly $\beta$-endorphin-(5-17) was formed by endopeptidase action on des-tyrosine- $\gamma$-endorphin (Burbach et al., 1980c).

In agreement with above described findings is the observation that $\left[{ }^{3} \mathrm{H}\right]-\beta$-endorphin-(2-13) was the only detectable product after push-pull perfusion of $\left[{ }^{3} \mathrm{H}-\mathrm{Phe}{ }^{4}\right]$-des-tyrosine- $\gamma$-endorphin in the rat nucleus caudatus (Burbach, 1983). Due to the position of the label, peptides like $\beta$-endorphin-(5-17) and shorter fragments escaped detection. This finding suggested that the product was formed during contact of destyrosine- $\gamma$-endorphin with extracellular tissue compartments locally in the brain.

Evidence for formation of a similar set of metabolites of des-tyrosine- $\gamma$-endorphin by peptidases in whole rat brain homogenates and striatal slices was provided by Schoemaker et al. (1982). Based on co-elution with synthetic peptides in HPLC these investigators reported the presence of $\beta$-endorphin-(6-17) as principal fragment and smaller quantities of $\beta$-endorphin-(4-17), -(5-17), -(10-17), -(12-17) and -(2-16) after exposure of destyrosine- $\gamma$-endorphin to homogenates and slices. The studies of Burbach et al. (1980c) and of Schoemaker et al. (1982) demonstrate that a combination of carboxypeptidase, aminopeptidase and endopeptidase activities are involved in the proteolytic conversion of des-tyrosine- $\gamma$-endorphin. The significance of production of $\beta$-endorphin-(6-17) is based on its property to retain the full biological activity of des-tyrosine- $\gamma$-endorphin (de Wied et al., 1980). Thus, des-tyrosine- $\gamma$-endorphin has been proposed as an active metabolite of $\beta$-endorphin (Burbach et al., 1980c; Pedigo et al., 1981; Schoemaker et al., 1982).

Above data are indicative for a preferred pathway of $\beta$-endorphin conversion (Fig. 4) (Burbach, 1980; Burbach et al., 1981; Burbach and de Kloet, 1982). The initial cleavage of $\beta$-endorphin takes place exclusively at two internal bonds, directed by the conformational properties of $\beta$-endorphin (see Section 4.4). An endopeptidase cleaves the $\mathrm{Leu}^{17}-\mathrm{Phe}^{18}$ bond and forms $\gamma$-endorphin $(\beta$-endorphin-(1-17) together with $\beta$-endorphin-(18-31). This endopeptidase ( $\gamma$-endorphin generating endopeptidase, $\gamma$ EGE) is distinctly different from lysosomal cathepsin D. The endopeptidase was active on $\beta$-endorphin at neutral $\mathrm{pH}$ and above and was not inhibited by $10^{-4} \mathrm{M}$ pepstatin (Burbach et al., 1980b). Lebouille and Burbach (1983, in preparation) developed a sensitive, 


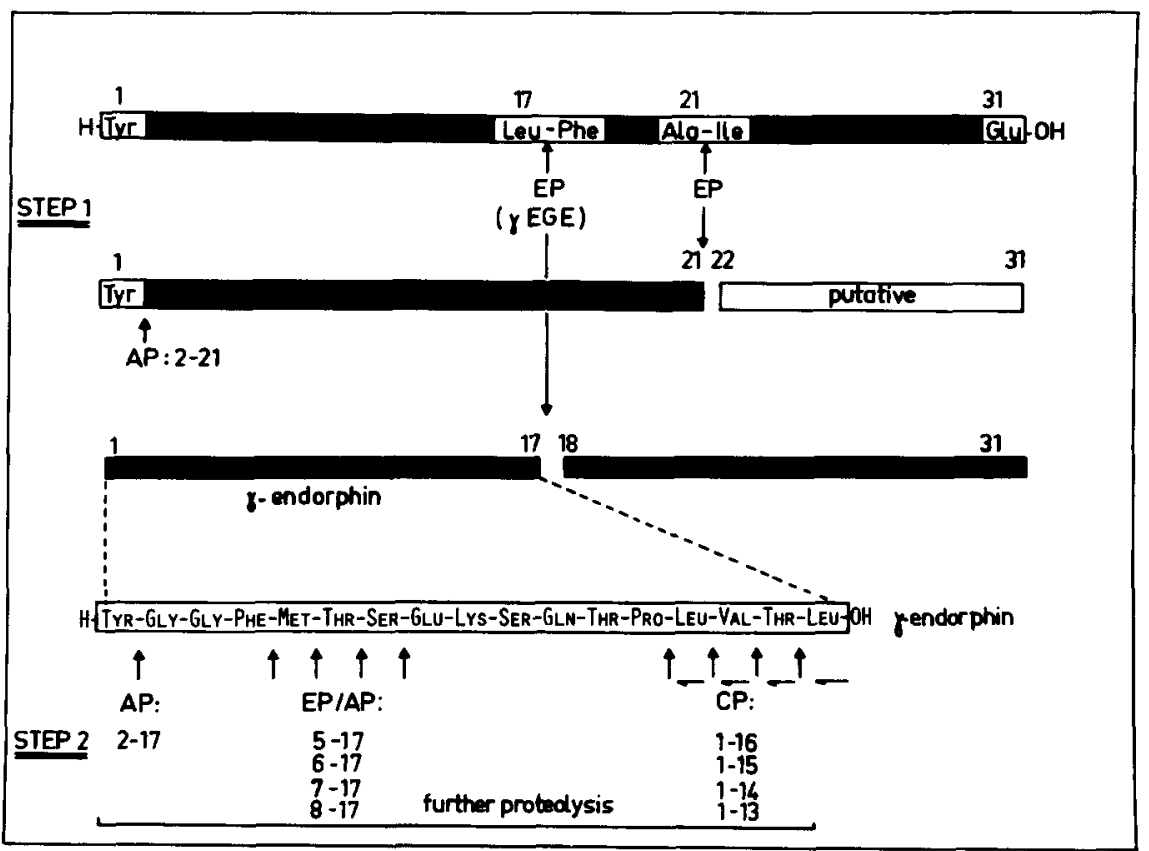

Fig. 4. Proteolytic conversion of $\beta$-endorphin by brain synaptic membranes. Proteolysis occurs in a step-wise fashion. STEP 1: initial cleavage of $\beta$-endorphin by endopeptidases (EP). Cleavage sites are located at the $\mathrm{Leu}^{17}-\mathrm{Phe}^{18}$ and $\mathrm{Ala}^{21}-\mathrm{Ile}^{22}$ bonds. Identified initial products are $\beta$-endorphin-(1-17) ( $\gamma$-endorphin) together with $\beta$-endorphin-(18-31), and $\beta$-endorphin-(1-21). The formation of $\beta$-endorphin-(22-31) is presumed. The endopeptidase activity responsible for the $\mathrm{Leu}^{17}-\mathrm{Phe}^{18}$ cleavage has been termed $\gamma$-endorphin generating endopeptidase $(\gamma$ EGE). STEP 2: secondary cleavage of products by exopeptidases. Aminopeptidase (AP) activity removes readily residue $\mathrm{Tyr}^{1}$, but does not seem to cleave the $\mathrm{Gly}^{2}-\mathrm{Gly}^{3}$ bond. Identified products are $\beta$-endorphin-(2-17) (des-tyrosine- $\gamma$-endorphin, DT $\gamma \mathrm{E}$ ), $\beta$-endorphin-(2-16) (des-tyrosine- $\alpha-$ endorphin) and $\beta$-endorphin-(2-21). Carboxypeptidase activity (CP) removes sequentially $\mathrm{COOH}-$ terminal amino acids from $\gamma$-endorphin, but stops at the Pro ${ }^{13}$ residue. Identified products are $\beta$-endorphin-(1-16) ( $\alpha$-endorphin), $\beta$-endorphin-(1-15), $-(1-14)$ and $-(1-13)$. In addition, the peptides $\beta$-endorphin- $(5-17),-(6-17),-(7-17)$ and $-(8-17)$ have been identified. Likely, they have been formed by putative endopeptidase action on $\gamma$-endorphin followed by aminopeptidase cleavage. All products are subject to further proteolysis and are therefore transient metabolites. The figure summarizes data taken from Burbach et al., 1980, 1981; Burbach and de Kloet, 1982.

quantitative assay for this endopeptidase $\gamma$ EGE by using a synthetic peptide substrate insensitive to cathepsin D. The $\gamma$ EGE measured by this assay had a $\mathrm{pH}$ optimum of 8.5 and was pepstatin-insensitive.

The identification of $\beta$-endorphin-(1-21) indicated that the $\mathrm{Ala}^{21}-\mathrm{Ile}^{22}$ in human $\beta$-endorphin was also cleaved (Fig. 4). Recently, a peptide with properties of $\beta$-endorphin-(1-21) has been detected in rat pituitary and brain tissue (unpublished).

While the conformation of $\beta$-endorphin is highly protective against exopeptidases, $\gamma$-endorphin is readily cleaved by amino- and carboxypeptidases (Burbach et al., 1981). Aminopeptidase activity forms des-tyrosine- $\gamma$-endorphin, but seems to stop at the $\mathrm{Gly}^{2}-\mathrm{Gly}^{3}$ sequence (Hersch et al., 1980). Carboxypeptidase activity removes sequentially the $\mathrm{COOH}$-terminal residues of $\gamma$-endorphin, but stops at the Pro ${ }^{13}$ residue, a known stop for carboxypeptidases (Hartsuck and Lipscomb, 1971). In addition, endopeptidases may act on $\gamma$-endorphin (Burbach et al., 1980b, 1981). These enzyme activities contribute to the eventual accumulation of fragments generated from $\beta$-endorphin. It was observed that the amounts of accumulated $\alpha$ - and $\gamma$-endorphins were highly dependent on small $\mathrm{pH}$ changes of the incubation medium. The ratio of $\alpha$ - to $\gamma$-type peptides shifted from 0.35 to 3.5 when pH changed from 6.7 to 5.9 (Burbach et al., 1980a; Burbach and de Wied, $1981,1982)$. This observation is explained by the differences in $\mathrm{pH}$ dependencies of peptidases involved. In particular, the carboxypeptidase converting $\gamma$-endorphin into $\alpha$-endorphin has an optimum of $\mathrm{pH} 5$ or below. It resembles a peptidase activity cleaving the COOH-terminus of adrenocorticotropin (Wang et al., 1983). Aminopeptidase activity 
releasing the $\mathrm{NH}_{2}$-terminal tyrosine has a pH optimum of 7 (Burbach et al., 1979a). In view of the outspoken central activities of $\alpha$ - and $\gamma$-endorphins, the various proteolytic activities involved in the conversion of $\beta$-endorphin may have a regulatory role in the formation of $\beta$-endorphin fragments. These findings of a highly $\mathrm{pH}$ sensitive enzyme system may indicate that endogenous factors controlling the activity of individual peptidases contribute to regulation of levels of $\alpha$-and $\gamma$-endorphins in situ.

\subsubsection{Cerebrospinal Fluid}

The susceptibility of $\beta$-endorphin and methionine-enkephalin ( $\beta$-endorphin- $(1-5))$ to proteolytic activity in human cerebrospinal fluid in vitro has been investigated (Burbach et al., 1979a; Burbach, 1982). Samples of cerebrospinal fluid were incubated with human $\beta$-endorphin-(1-31) and $\beta$-endorphin-(1-5) for $5 \mathrm{hr}$ at $37^{\circ} \mathrm{C}$ and the amounts of peptides were assessed by radioimmunoassay. No decrease in immunoreactivity was found for the two peptides when human cerebrospinal fluid of non-psychiatric patients or schizophrenic patients was used (Burbach et al., 1979a). It was concluded that endorphins are not significantly degraded by proteolytic activities in cerebrospinal fluid. The studies suggested that altered levels of endorphins in cerebrospinal fluid are a reflection of changes in cellular metabolism and release of endorphins and not due to proteolytic enzymes in the cerebrospinal fluid.

\subsubsection{Purified Enzymes from Brain Tissue}

The action of several proteolytic enzymes purified from brain tissue on $\beta$-endorphin and related peptides has been investigated. These enzymes can be grouped in three classes on the basis of the site of cleavage in the $\beta$-endorphin sequence.

The Leu ${ }^{17}-\mathrm{Phe}^{18}$ bond of $\beta$-endorphin is a site sensitive to the action of the purified acid proteinase cathepsin D. Cathepsin D purified from calf brain by affinity chromatography on pepstatin-Sepharose (Benuck et al., 1978a) exclusively cleaved $\beta$-endorphin at the Leu $^{17}-\mathrm{Phe}^{18}$ bond forming $\gamma$-endorphin and $\beta$-endorphin-(18-31) (Gráf et al., 1979b). The enzyme displayed activity in the $\mathrm{pH}$ range $3.0-7.0$ and was completely inhibited by $10^{-6} \mathrm{M}$ pepstatin. Cathepsin D purified from other tissues, such as human pituitaries (Benuck et al., 1978a; Barát et al., 1979) and bovine spleen, obtained as a commercial preparation (Burbach et al., 1980b), cleaved the Leu-Phe bond of $\beta$-endorphin or $\beta$-LPH similarly (see also section 3.1.2.).

The cleavage of the $\mathrm{Met}^{5}-\mathrm{Thr}^{6}$ bond of $\mathrm{NH}_{2}$-terminal $\beta$-endorphin sequences by purified brain enzymes has been described. Koida and coworkers (1979; Aono et al., 1978) purified such an enzyme by affinity chromatography using immobilized $\beta$-endorphin-(2-7). This enzyme selectively cleaved the $\mathrm{Met}^{5}-\mathrm{Thr}^{6}$ bond. It may resemble an enzyme activity which was detected in crude fractions of brain tissue cleaving the same peptide bond of $\beta$-endorphin or derivatives (Knight and Klee, 1979; Austen et al., 1977a; Austen and Smyth, 1978; Smyth and Snell, 1977b; Palmour et al., 1978; Orlowski et al., 1980; Burbach et al., 1981).

Hersch et al. $(1980,1981)$ purified an aminopeptidase from bovine brain which removed the $\mathrm{NH}_{2}$-terminal tyrosine from endorphins. The hydrolysis of the $\mathrm{Tyr}^{1}-\mathrm{Gly}^{2}$ bond was most rapid from $\beta$-endorphin-(1-5). The rate of hydrolysis of $\beta$-endorphin-(1-16) and -(1-17) was approximately $30 \%$ of that of $\beta$-endorphin-(1-5), whereas $\beta$-endorphin-(1-31) was cleaved at a rate of only $0.5 \%$ as compared to $\beta$-endorphin-(1-5) (Hersch et al., 1980). The relative resistance of $\beta$-endorphin is also observed with aminopeptidase activity from other sources (Austen and Smyth, 1977c; Burbach et al., 1979b) and is related to conformational restraints of the peptide for proteolytic attack (Austen and Smyth, 1977a,b; Geisow and Smyth, 1977; Nicolas et al., 1981). Interestingly, an aminopeptidase purified from human brain removing the $\mathrm{NH}_{2}$-terminal tyrosine from $\beta$-endorphin-(1-5) is unable to cleave the $\mathrm{NH}_{2}$-terminus of $\beta$-endorphin-(1-16) (Traficante et al., 1980). 
Cathepsin B purified from bovine brain has been reported to cleave $\beta$-endorphin (Suhar and Marks, 1979). However, the site of cleavage has not been determined as yet.

\subsection{Proteolysis of $\beta$-Endorphin by Pituitary Enzymes}

The $\beta$-endorphin fragments $\alpha$ - and $\gamma$-endorphin ( $\beta$-endorphin-(1-16), $-(1-17)$, respectively) occur in the pituitary pointing to the existence of proteolytic enzymes in the pituitary cleaving the $\mathrm{Thr}^{16}-\mathrm{Leu}^{17}-\mathrm{Phe}^{18}$ region of $\beta$-endorphin. Studies performed on porcine $\beta$-lipotropin-(1-91) revealed the presence of endopeptidases cleaving the $\mathrm{Leu}^{77}-\mathrm{Phe}^{78}$ and $\mathrm{Lys}^{79}-\mathrm{Asn}^{80}$ bonds of $\beta$-lipotropin (Gráf and Kenessey, 1976; Gráf et al., 1977; Benuck et al., 1978b; see also Section 3.1.2). These data suggest that these enzyme activities also cleave the same bonds of $\beta$-endorphin. Indeed, cathepsin D purified from human pituitary tissue cleaved the Leu ${ }^{17}-\mathrm{Phe}^{18}$ of $\beta$-endorphin (Gráf et al., 1979b; Benuck et al., 1978b). In preliminary experiments Lebouille and Burbach detected soluble and particulate pepstatin-insensitive neutral peptidase activities cleaving the Leu-Phe bond (unpublished). In addition a cation-sensitive endopeptidase that splits the $\mathrm{Met}^{5}-\mathrm{Thr}^{6}$ bond of $\beta$-endorphin-(1-16) has been purified from bovine pituitaries (Orlowski et al., 1980).

\subsection{PROTEOLYSIS OF $\beta$-ENDORPHIN By ENZYMes OF Peripheral Organs}

Proteolysis of $\beta$-endorphin by subcellular fractions of peripheral organs has been observed. $\left[{ }^{125} \mathrm{I}\right]-\beta$-Endorphin and its analog $\left[{ }^{125} \mathrm{I}\right]-\left[\mathrm{Leu}^{5}\right]-\beta$-endorphin were degraded by supernatant and membranes of kidney (Palmour et al., 1978). A rapid formation of free $\left[{ }^{125} \mathrm{I}\right] \mathrm{tyrosine}$ was observed and small amounts of $\left[{ }^{125} \mathrm{I}\right]-\beta$-endorphin-(1-17), $-(1-8),-(1-5)$, and $-(1-4)$ were detected. The degradation rate was highest in the supernatant fraction. Activities in supernatant and membranes were to some extent sensitive to bacitracin.

The presence of $\beta$-endorphin and fragments in a myenteric plexus preparation of guinea-pig ileum, which is sensitive to the opioid activities of $\beta$-endorphin, prompted Opmeer and colleagues to investigate the proteolysis of $\beta$-endorphin by membranes from this tissue (Opmeer et al., 1980, 1982). $\beta$-Endorphin was converted by these membranes in vitro into $\beta$-endorphin-(1-17), $-(1-16),-(2-17)$ and $-(2-16)$. These peptides appeared as transient metabolites during incubation. $\beta$-Endorphin-(1-17) accumulated in largest quantities. These data suggest that $\beta$-endorphin is converted in the myenteric plexus by similar proteolytic mechanisms as in the brain (Fig. 4). The time course of accumulation of $\beta$-endorphin fragments during proteolysis by myenteric plexus membranes was changed after exposure of the tissue to morphine (Opmeer et al., 1982). Combined with the observation of altered endogenous levels of $\beta$-endorphin fragments in the myenteric plexus after morphine treatment (Opmeer et al., 1980), it was suggested that chronic morphine exposure increased the turnover of $\beta$-endorphin-(1-17).

It has been reported that homogenates of the whole gut, mucosa and myenteric plexus regions convert $\beta$-endorphin similarly into $\alpha$-and $\gamma$-endorphins and related fragments. However, quantitative differences between these tissues have been observed (Davis et al., 1983).

\subsection{Action of Purified Enzymes on $\beta$-Endorphin: Conformational Restraints FOR PROTEOLYSIS}

The remarkable conformational properties of $\beta$-endorphin were first recognized by Smyth and co-workers investigating the susceptibility of the peptide to exo- and endopeptidases (Geisow and Smyth, 1977a; Austen and Smyth, 1977a,b,c). The conformation protects both $\mathrm{NH}_{2}$ and $\mathrm{COOH}$ termini of $\beta$-endorphin against exopeptidases and leaves the mid-portion of the peptide open for proteolytic attack. This conformational property appears to direct the proteolytic cleavage of the peptide by purified enzymes as well as by proteolytic activities in tissue fractions. The stepwise formation of neuroactive $\beta$-endorphin fragments such as $\gamma$ - and $\alpha$-endorphins seems to be partly due to the 
preferred conformation of $\beta$-endorphin. The evidence for this conformation based on the action of purified proteolytic enzymes is briefly reviewed here.

It was noticed that $\beta$-endorphin-(1-31) was unusually stable during treatment with carboxypeptidase A (Geisow and Smyth, 1977a) and aminopeptidase M (Austen and Smyth, 1977c). On the other hand $\beta$-endorphin is easily cleaved by various endopeptidases. These endopeptidases initially cleave peptide bonds in the 16-22 region of $\beta$-endorphin, while only at more stringent incubation conditions additional bonds are cleaved. Rennin, chymotrypsin, trypsin and Armillaria protease initially cleave the $\mathrm{Leu}^{17}-\mathrm{Phe}^{18}$, $\mathrm{Phe}^{18}-\mathrm{Lys}^{19}$, Lys $^{19}-\mathrm{Asn}^{20}$, and $\mathrm{Phe}^{18}-\mathrm{Lys}^{19}$ bonds of $\beta$-endorphin respectively. Secondary cleavage sites are the $\mathrm{Phe}^{4}-\mathrm{Met}^{5}$ (rennin, chymotrypsin), $\mathrm{Lys}^{9}-\mathrm{Ser}^{10}$ (trypsin) and $\mathrm{Glu}^{8}-\mathrm{Lys}^{9}$ bonds (Armillaria protease) (Austen and Smyth, 1977a,b). Thermolysin, a metalloendopeptidase with broad specificity, initially cleaves the $\mathrm{Ala}^{21}-\mathrm{Ile}^{22}$ bond at very short incubation time. Longer incubation results in cleavage of many bonds (Nicolas et al., 1980).

\section{FATE OF LIPOTROPINS AND ENDORPHINS IN THE PERIPHERAL CIRCULATION}

In the peripheral circulation endogenous lipotropins and endorphins, secreted from the pituitary gland or administered exogenously, are subject to distribution and elimination. Studies on the metabolic fate of lipotropins and endorphins have mainly focused on the half-lifes $\left(t_{1 / 2}\right)$ of endogenous and exogenous peptides in the blood and on the stability of lipotropins and endorphins in plasma in vitro.

\subsection{Half-Life}

The plasma half-lifes of exogenous lipotropins and $\beta$-endorphin have been assessed after intravenous injection of the peptides, usually by measuring the immunoreactivity of the peptide in a radioimmunoassay system. To control for possible crossreaction of degradation products of the administered peptides in these assay systems gel filtration chromatography has been employed by several investigators. Two studies have employed radioactively labeled peptides (Houghton et al., 1980; Verhoef et al., 1983).

In general the decay of peptide concentrations in the plasma shows a biphasic pattern. The initial decline in lipotropin and $\beta$-endorphin levels is representative for the distribution of the peptides over different extravascular spaces, while the secondary, slower decline is due to the elimination of the peptides from the circulation mainly by metabolic processes. Most studies recognize the biphasic disappearance rates of lipotropins and $\beta$-endorphin, and often the pharmacokinetic parameters associated with each separate phase, are derived mathematically (e.g. Gibaldi and Perrier, 1975). In other cases an 'overall' half-life is given, which mostly approximates the plasma half-life associated with the secondary or elimination phase.

\subsubsection{Endogenous Peptides}

The disappearance rates of endogenous lipotropins and endorphins from the peripheral circulation can only be determined in subjects with elevated plasma levels of these peptides in which the secretion of these peptides is abruptly suppressed by infusion of corticosteroids. After suppression of the pituitary hypersecretion by cortisol in a patient with Addison's disease, Bertagna et al. (1981) observed a rapid fall in both immunoreactive $\gamma$-lipotropin and immunoreactive $\beta$-lipotropin including $\beta$-endorphin. The initial and secondary half-lifes $\left(t_{1 / 2}\right)$ of $\gamma$-lipotropin were 80 and $170 \mathrm{~min}$, and for $\beta$-lipotropin $/ \beta$-endorphin 100 and $180 \mathrm{~min}$. Data on the individual peptides were subsequently obtained after separation by gel filtration showing similar values for $\gamma$-lipotropin and $\beta$-lipotropin, whereas $\beta$-endorphin disappeared much more rapidly with a half-life of approximately $40 \mathrm{~min}$ in the initial phase. In the study of Tanaka et al. (1978b) the disappearance of immunoreactive $\beta$-melanotropin was followed with time in three female 
patients with Addison's disease during infusion of cortisol. It was shown that the immunoreactivity detected by the $\beta$-MSH radioimmunoassay in human plasma represented the lipotropins $\gamma$-lipotropin and $\beta$-lipotropin (Tanaka et al., 1978a,b; Bloomfield et al., 1974; Bachelot et al., 1977). Tanaka et al., (1978b) found that in two of the three patients investigated the disappearance of lipotropins was monophasic, with $t_{1 / 2}$-values of 133 and $72 \mathrm{~min}$ respectively. In the third patient the disappearance was biphasic, with an initial $t_{1 / 2}$ of $44 \mathrm{~min}$ and $t_{1 / 2}$ of $100 \mathrm{~min}$ in the second part of the disappearance curve. The average overall $t_{1 / 2}$ for disappearance of endogenous lipotropins in these patients was approximately $80 \mathrm{~min}$, while that of immunoreactive ACTH was 40 min (Tanaka et al., 1978a,b).

\subsubsection{Exogenous Peptides}

A number of reports have presented experiments on the disappearance of $\beta$-endorphin and $\beta$-lipotropin in plasma after systemic injection. In these studies largely different doses of administered peptides have been employed and experiments have been carried out in different species.

In human subjects the disappearance of intravenously administered $\beta$-endorphin and $\beta$-lipotropin was assessed by specific radioimmunoassay procedures. Liotta and coworkers, administering intravenously boli of $250 \mu \mathrm{g}$ to $370 \mu \mathrm{g}$ of highly purified human $\beta$-lipotropin found that the disappearance of $\beta$-lipotropin was biphasic with overall $t_{1 / 2}$-values ranging from 33 to $69 \mathrm{~min}$ (Liotta et al., 1978; Aronin et al., 1981). This $t_{1 / 2}$ is based on calculated values of the apparent volume of distribution $\left(V_{\mathrm{d}}\right)$ and metabolic clearance rate (MCR), which were generated by integration of multi-exponential equations (Liotta et al., 1978). In these experiments the MCR for human $\beta$-lipotropin was between 0.57 and $0.231 / \mathrm{min}$.

After intravenous administration of $100 \mu \mathrm{g} \beta$-endorphin to three normal human subjects Aronin et al. (1981) found a biphasic disappearance of the peptide with $t_{1 / 2}$ of 32,51 and $50 \mathrm{~min}$ and a MCR of $0.49,0.47$, and $0.45 \mathrm{l} / \mathrm{min}$, respectively. From comparison with the pharmacokinetic data obtained with $\beta$-lipotropin in the same series of experiments, the authors suggest that $\beta$-endorphin has both a more rapid MCR and a more rapid initial disappearance than $\beta$-lipotropin (Aronin et al., 1981). At $30 \mathrm{~min}$ after injection the average percentage of peptide remaining was $1.53 \% / 1$ for $\beta$-endorphin and $2.25 \% / 1$ for $\beta$-lipotropin.

Foley et al. (1979) studied the disappearance of intravenously administered high doses ( $5 \mathrm{mg}$ and $10 \mathrm{mg}$ ) of synthetic human $\beta$-endorphin to patients suffering from chronic pain due to cancer. The $t_{1 / 2}$ values of the distribution and elimination phases were between 2.3 and $7.4 \mathrm{~min}$, and 27 and $132 \mathrm{~min}$, respectively. The MCR's obtained by Foley et al. (1979) (average $5.6 \mathrm{ml} \mathrm{min}-1 \mathrm{~kg}^{-1}, n=4$ ) were comparable to those of Aronin et al. (1981) (average $7.8 \mathrm{ml} \mathrm{min}^{-1} \mathrm{~kg}^{-1}$ ). The two studies, however, are difficult to compare for pharmacokinetic data due to large differences in dose $(5$ or $10 \mathrm{mg}$ vs $100 \mu \mathrm{g})$ and in methods used for calculation of the pharmacokinetic data.

After intravenous administration of $\beta$-endorphin to psychiatric patients in doses ranging from 3 to $9 \mathrm{mg}$, Lehman et al. (1979) reported a monophasic disappearance rate of the peptide with a half-life varying between 12 and $35 \mathrm{~min}$. Berger et al. (1980) found a biphasic disappearance with $t_{1 / 2}$-values of 15 ( $\alpha$-phase) and 39 ( $\beta$-phase) min after an intravenous bolus injection of $20 \mathrm{mg}$ of $\beta$-endorphin to schizophrenic patients. These values approximate the data of Reid et al. (1981)), who investigated the plasma disappearance rate of $\beta$-endorphin after a bolus injection of $2.5 \mathrm{mg}$. These authors derived three disappearance constants from their experimental data: the initial half-life was $4 \mathrm{~min}$, the midrange component had a half-life of $13 \mathrm{~min}$ and the slow component had a half-life of $46 \mathrm{~min}$.

In the rat $150 \mu \mathrm{g}$ of intravenously injected $\beta$-lipotropin had a plasma half-life of $4.2 \mathrm{~min}$; $\beta$-endorphin, in the same dose, had a half-life of $9.2 \mathrm{~min}$ as determined by Chang et al. (1978). In contrast, Pezalla et al. (1978) found that in the rabbit purified ovine $\beta$-endorphin had a shorter plasma half-life than ovine $\beta$-lipotropin when administered in equimolar 
TABLE 5. Pharmacokinetics of Intravenously Administered $\beta$-endorphin and $\beta$-lipotropin

\begin{tabular}{|c|c|c|c|c|c|}
\hline Peptide & $\begin{array}{c}\text { Approximate } \\
\text { i.v. } \\
\text { Dose }(\mu \mathrm{g}) \\
\end{array}$ & Species/Subject & Curve $^{\text {Dis }}$ & $\begin{array}{l}\text { pearance } \\
t_{1 / 2}(\min )\end{array}$ & Reference \\
\hline$\beta$-endorphin & 100 & human/normal & biphasic & 32 overall & Aronin et al., 1981 \\
\hline$\beta$-endorphin & 100 & human/normal & biphasic & 51 overall & Aronin et al., 1981 \\
\hline$\beta$-endorphin & 100 & human/normal & biphasic & 50 overall & Aronin et al., 1981 \\
\hline$\beta$-endorphin & 5,000 & human/chronic pain & biphasic & $\alpha: 7.4 ; \beta: 27$ & Foley et al., 1979 \\
\hline$\beta$-endorphin & 10,000 & human/chronic pain & biphasic & $\alpha: 6.7 ; \beta: 39$ & Foley et al., 1979 \\
\hline$\beta$-endorphin & 10,000 & human/chronic pain & biphasic & $\alpha: 4.9 ; \beta: 45$ & Foley et al., 1979 \\
\hline$\beta$-endorphin & 3,000 & human/psychiatric & monophasic & 12 & Lehman et al., 1979 \\
\hline$\beta$-endorphin & 9,000 & human/psychiatric & monophasic & 35 & Lehman et al., 1979 \\
\hline$\beta$-endorphin & 20,000 & human/schizophrenic & biphasic & $\alpha: 15 ; \beta: 39$ & Berger et al., 1980 \\
\hline$\beta$-endorphin & 2,500 & human/normal $(n=3)$ & triphasic & $\begin{array}{l}\alpha: 4.1 ; \beta: 13.1 \\
\gamma: 46.2\end{array}$ & Reid et al., 1981 \\
\hline$\beta$-endorphin-(2-17) & 5 & rat & biphasic & $\begin{array}{l}\alpha: 0.7 ; \beta: 5.5 \\
\text { biological: } 0.9\end{array}$ & Verhoef et al., 1983 \\
\hline$\beta$-endorphin- $(\epsilon$ & 3 & rat & biph & biological: 0.6 & Verhoef $e$ \\
\hline$\beta$-endorphin & 150 & rat & biphasic & 9.2 overall & Chang et al., 1978 \\
\hline$\beta$-endorphin & 0.3 & rat & biphasic & 2.0 overall & $\begin{array}{l}\text { Houghten et al., } \\
\quad 1980\end{array}$ \\
\hline$\beta$-endorphin & 1.5 & rabbit & biphasic & 4.0 overall & $\begin{array}{l}\text { Houghten et al., } \\
\quad 1980\end{array}$ \\
\hline$\beta$-endorphin & 70 & rabbit & biphasic & $4.8 \mathrm{o}$ & Pezalla et al., 1978 \\
\hline$\beta$-endorphin & 125 & rabbit & biphasic & 14 overall & Merin et al., 1980 \\
\hline$\beta$-lipotropin & 270 & human/normal $(n=3)$ & biphasic & 37.3 overall & Liotta et al., 1978 \\
\hline$\beta$-lipotropin & 250 or 370 & human/normal & biphasic & 45 overall & Aronin et al., 1981 \\
\hline$\beta$-lipotropin & 250 or 370 & human/normal & biphasic & 69 overall & Aronin et al., 1981 \\
\hline$\beta$-lipotropin & 250 or 370 & human/normal & biphasic & 33 overall & Aronin et al., 1981 \\
\hline$\beta$-lipotropin & 150 & rat & biphasic & 4.2 overall & Chang et al., 1978 \\
\hline$\beta$-lipotropin & 250 & rabbit & biphasic & 13.7 overall & Pezalla et al., 1978 \\
\hline$\beta$-melanotropin & 100 & rabbit & biphasic & 5.1 overall & Pezalla et al., 1978 \\
\hline
\end{tabular}

amounts (approximately $70 \mu \mathrm{g}$ of $\beta$-endorphin, $t_{1 / 2}=4.8 \mathrm{~min} ; 250 \mu \mathrm{g}$ of $\beta$-LPH, $t_{1 / 2}=13.7 \mathrm{~min}$ ). Porcine $\beta$-melanotropin had a half-life of $5.1 \mathrm{~min}$. The plasma half-life of $\beta$-endorphin in the rabbit was reported to be approximately $14 \mathrm{~min}$ by Merin et al. (1980). Using synthetic tritiated $\beta$-endorphin Houghton et al. (1980) found that in the rat the initial plasma half-life of $0.3 \mu \mathrm{g} \beta$-endorphin was approximately $2 \mathrm{~min}$, while in the rabbit the initial half-life of $1.5 \mu \mathrm{g} \beta$-endorphin was $5 \mathrm{~min}$. These values are lower than those of Chang et al. (1978), Pezalla et al. (1978), and Merin et al. (1980) possibly due to the methodology measuring intact peptide instead of immunoreactivity. Verhoef et al. (1983) investigated the plasma disappearance of the $\beta$-endorphin fragments $\beta$-endorphin-(2-17) (des-tyrosine- $\gamma$-endorphin) and $\beta$-endorphin-(6-17) (des-enkephalin- $\gamma$-endorphin) after intravenous administration in the rat. The peptides carried a $\left[{ }^{3} \mathrm{H}\right]$-label in residue $\mathrm{Phe}^{4}$ and Lys $^{9}$, respectively. Separation of intact peptide from radioactive products recovered from plasma were obtained by high-pressure liquid chromatography. $\beta$-Endorphin-(2-17) had a biphasic disappearance curve; the calculated biological half-life was $0.9 \mathrm{~min}$. The biological half-life of $\beta$-endorphin-(6-17) was 0.6 min (Table 5).

The data on the disappearance of $\beta$-endorphin and $\beta$-lipotropin after exogenous administration are summarized in Table 5. In humans the disappearance rate of these peptides appears to follow a biphasic pattern with a rapid initial decline in plasma concentration, followed by a slower elimination phase. Although in the various studies a variety of doses has been used to assess the pharmacokinetic data, generally the half-life of $\beta$-endorphin found is in the order of $20-50 \mathrm{~min}$. There is a tendency that the half-life of $\beta$-lipotropin is somewhat longer than that of $\beta$-endorphin as indicated by studies on endogenous as well as exogenous $\beta$-lipotropin and endorphins (Aronin et al., 1981; Bertagna et al., 1981). Slower disappearance rates are found after suppressing the pituitary secretion by cortisol. These values, however, may be influenced by incomplete suppression during the experiments.

In rodents, rats and rabbits, the half-life of $\beta$-endorphin and $\beta$-lipotropin is shorter than in humans varying between 2 and $14 \mathrm{~min}$. Such differences between large and small species 
also exist for ACTH (Reith and Neidle, 1981). There is no general agreement on a difference in disappearance rates of $\beta$-endorphin and $\beta$-lipotropin in rabbits (Pezalla et al., 1978; Chang et al., 1978).

\subsection{Proteolysis by Enzymes in the Peripheral Circulation}

Several studies have been concerned with the proteolytic cleavage of $\beta$-lipotropin and $\beta$-endorphin in the peripheral circulation. Liotta and co-workers (Liotta et al., 1978; Aronin et al., 1981) showed that after intravenous injection of $\beta$-lipotropin in humans immunoreactivity measured in radioimmunoassay systems for $\beta$-lipotropin represented intact $\beta$-lipotropin. Immunoreactivity eluted in a single peak with [ $\left.{ }^{125} \mathrm{I}\right]-\beta$-lipotropin during gel filtration while no conversion to $\beta$-endorphin or $\mathrm{NH}_{2}$-terminal sequences could be detected. In contrast with these data Pezalla et al. (1978) reported that in the rabbit $\beta$-lipotropin was cleaved into peptides tentatively identified as $\gamma$-lipotropin and $\beta$-endorphin. Characterization of these peptides was based on separation of plasma samples by gel filtration on Sephadex G- 50 and detection by radioimmunoassay systems directed against different portions of the $\beta$-lipotropin sequence.

The proteolytic cleavage of endorphins in vivo circulating in the blood or in vitro has been investigated in more detail. Merin et al. (1980) did not detect any degradation products of $\beta$-endorphin in the plasma after an intravenous bolus injection in rabbits. These authors employed gel filtration and a radioimmunoassay system. The absence of metabolites may be due to the rather strict specificity of the $\beta$-endorphin antiserum used. From the injecting of tritiated $\beta$-endorphin in the rabbit, Houghten et al. (1980) found that after $45 \mathrm{~min} 70 \%$ of the total radioactivity in plasma represented intact $\beta$-endorphin. In the plasma of the rat at least $50 \%$ of the total radioactivity represented intact $\beta$-endorphin as shown in different chromatographic systems. After subcutaneous injection of the $\beta$-endorphin fragment $\left[{ }^{3} \mathrm{H}\right.$-Lys $\left.{ }^{9}\right]-\beta$-endorphin-(6-17) in the rat Verhoef $e t$ al. (1983) using high-pressure liquid chromatography detected three radioactive metabolites in the plasma. The major product was $\left[{ }^{3} \mathrm{H}\right]$ lysine; minor components had chromatographic properties of $\beta$-endorphin-(6-15) and -(6-14). After intravenous administration only very small quantities of $\beta$-endorphin-(6-15) were found in addition to the free $\left[{ }^{3} \mathrm{H}\right] \mathrm{amino}$ acids.

Houghten et al. (1980) found by radioimmunoassay determination that during in vitro incubation of $\beta$-endorphin with rat plasma the peptide was degraded slowly; after an incubation period of $3 \mathrm{hr}$ at $37^{\circ} \mathrm{C} 60 \%$ of $\beta$-endorphin remained intact. In human serum and plasma the levels of immunoreactive $\beta$-endorphin are fluctuating depending on the time and temperature of storage, indicating the presence of enzyme activities generating $\beta$-endorphin, likely from $\beta$-lipotropin, as well as degrading the peptide (Wiedemann $e t a l$., 1979). Burbach et al. (1979b) observed a high resistance of $\beta$-endorphin to proteolytic activity in human plasma. In diluted plasma no significant decrease in immunoreactive $\beta$-endorphin was detected during incubation of $2 \mathrm{hr}$ at $37^{\circ} \mathrm{C}$. Similarly, Rossier et al. (1977) did not observe any degradation of $\beta$-endorphin in diluted rat serum after $30 \mathrm{~min}$ of incubation at $37^{\circ} \mathrm{C}$. However, during incubation of human $\left[{ }^{125} \mathrm{I}\right]-\beta$-endorphin-(1-31) in diluted plasma a slow release of $\left.{ }^{125} \mathrm{I}\right]$ tyrosine was observed, indicating that a portion of the peptide was cleaved to a minor extent by plasma proteinases (Burbach et al., 1979b). The immunoreactivity of the $\beta$-endorphin fragments $\alpha$ - and $\gamma$-endorphin, and destyrosine- $\gamma$-endorphin decreased detectably with $80 \%$ remaining after $2 \mathrm{hr}$ at $37^{\circ} \mathrm{C}$ in diluted human plasma. Since the antisera for $\alpha$ - and $\gamma$-endorphin used recognized the $\mathrm{COOH}$ terminal sequences of the peptides (Loeber et al., 1979; Loeber and Verhoef, 1981) these data indicated that the $\mathrm{COOH}$-termini of these peptides were rather resistant to attack by plasma enzymes. By following the release of the $\mathrm{NH}_{2}$-terminal tyrosine from iodinated $\beta$-endorphin fragments, it appeared that $\mathrm{NH}_{2}$-terminus of $\beta$-endorphin-(1-9) was cleaved rapidly (half maximal release at $8.5 \mathrm{~min}$ ), while $\alpha$ - and $\gamma$-endorphin were more resistant to attack of the $\mathrm{NH}_{2}$-terminus (half maximal release of [ $\left.{ }^{125} \mathrm{I}\right]$ tyrosine at $64 \mathrm{~min}$ ). These data indicate that the main enzyme activity cleaving short endorphin fragments in serum is an aminopeptidase-like activity. $\beta$-Endorphin is resistant to this type of cleavage, while the 
susceptibility of the $\beta$-endorphin fragments to aminopeptidase cleavage is a function of their chain length (Austen and Smyth, 1977a; Burbach et al., 1979b; Hersch et al., 1980).

\section{CONCLUDING REMARKS}

This review has focused on the proteolysis of lipotropins and endorphins. Three fundamentally different functional aspects of the proteolytic enzyme systems are considered. One enzyme system is part of the chain of intracellular events that process precursor polypeptides into the products of biosynthesis. It is responsible for biosynthesis of $\beta$-endorphin by cleaving its precursor pro-opiomelanocortin. The other uses the biosynthetic end products as substrates in order to generate a variety of peptides with modified activities, as apparent from the biotransformation of $\beta$-endorphin into smaller fragments with distinct central activities. A third enzyme system inactivates biological active peptides. The family of peptides related to lipotropins and endorphins provide outstanding examples of these three different proteolytic systems.

The proteolytic processing of the multifunctional precursor pro-opiomelanocortin is a well defined example of the mechanism of peptide biosynthesis and illustrates the determining role of the processing enzymes. These processing enzymes virtually all recognize pairs of basic amino acids and determine the nature of the biologically active peptides produced by a certain cell type. For instance, $\beta$-lipotropin is one of the end products of the processing of pro-opiomelanocortin in the anterior lobe of the pituitary gland, while enzymes of the intermediate lobe and the brain use $\beta$-lipotropin as substrate to produce $\beta$-endorphin. Consequently $\beta$-lipotropin has been adopted as substrate in studies on these processing enzymes. As yet, two types of proteolytic enzymes have been recognized that fulfill several criteria for processing enzymes: firstly, serine proteases with a basic $\mathrm{pH}$ optimum and with similarity to the kalikreins, and secondly, thiol argynyl proteases with acidic working range. Direct evidence of the physiological involvement of either of these enzymes in the processing of prohormones is still lacking.

In the early stages of endorphin research the proteolytic cleavage of $\beta$-endorphin was considered to be part of a degradative mechanism. However, the findings of unique sets of $\beta$-endorphin fragments endogenously in brain and pituitary tissue (e.g. $\alpha$ - and $\gamma$-endorphins) and the discovery of their separate and distinct biological activities has substantiated the concept that biotransformation of $\beta$-endorphin is a functional mechanism to generate and regulate active peptides. By now we have begun to learn enough about the properties of this type of proteolysis that criteria for enzymes involved in biotransformation can be indicated. These criteria should take into account the localization of enzyme and substrate, the biological significance of the products of enzyme action, and a regulatory role of the enzyme.

(1) If biotransformation is secondary to the intracellular biosynthetic processing, the enzymes should use end products of biosynthesis as substrates and be localized strategically towards these end products, e.g. linked with sites of storage or release. With respect to the compartmentalization intra- as well as extracellular sites of biotransformation can be considered. For example, $\alpha$ - and $\gamma$-endorphins are at one hand present in the same cells as their precursor peptide $\beta$-endorphin and are co-released upon stimulation, e.g. from the pars intermedia of the pituitary gland, suggesting a intracellular site of biotransformation, possibly intragranular. At the other hand, formation of $\alpha$ - and $\gamma$-endorphins can be mediated by enzymes in synaptic membranes and soluble fractions, suggesting a postsecretional site of biotransformation of $\beta$-endorphin.

(2) If biotransformation serves to generate novel biological activities, the products of enzyme action should display activities unique to them and distinct from those of their precursors, and be endogenously present.

(3) If biotransformation has a regulatory role, the enzyme activity should be able to accommodate the availability of its products to changed situations. This implicates that a functional relationship between activity of the enzymes and the endogenous levels of the products exists. 
In contrast to biosynthetic processing and biotransformation, the inactivation of biologically active peptides can be accomplished by many if not all tissues. In general tissues display a high degradative capacity towards peptides. In the peripheral circulation this leads to short biological half-lives of peptides.

Future research that aims to define functional aspects of proteolytic enzymes involved in the metabolism of biologically active peptides will largely depend on knowledge of the properties of these proteolytic enzymes. Studies in this direction will be greatly assisted by the development of synthetic substrates that allow specific and sensitive assessment of enzyme activity. Also, studies employing specific inhibitors or antisera can be used to probe the enzymes and to modulate enzyme activity. Such studies can be informative for defining a regulatory role of the enzymes. In addition it will be necessary to extend our knowledge of the forms and biological activities of endogenous peptides and their metabolites. The family of peptides related to the lipotropins and endorphins provides an outstanding biological system to define the roles of proteolytic enzymes in biosynthesis, biotransformation and inactivation.

Acknowledgement-The author is grateful to Mrs. Marianne van Grondelle-van 't Riet for excellent secretarial assistance during preparation of the manuscript.

\section{REFERENCES}

Akopyan, T., Arutunyan, A. and Oganisyan, A. (1982) Fragments formed from neuropeptides upon action of hypothalamic endopeptidases. In: Chemistry of Peptides and Proteins, Vol. 1, pp. 99-102, Voelter, W., WünSCh, E., Ovchinnikov, J. and Ivanov, V. (eds) Waiter de Gruyter \& Co, Berlin.

Aono, J., TAKAHASHI, M. and KoIDA, M. (1978) An assay method of brain enzyme carving $\beta$-endorphin inte methionine enkephalin. Jap. J. Pharmac. 28: 930-932.

Aronin, N., Wiesen, M., Liotta, A. S., Schussler, G. C. and Krieger, D. T. (1981) Comparative metabolic clearance rates of $\beta$-endorphin and $\beta$-lipotropin in humans. Life Sci. 29: 1265-1269.

arutyunyan, A. A., Akopyan, T. N., Organisyan, A. I., Galfayan, V. T. and Galoyan, A. A. (1981) Degradation of ACTH and $\beta$-lipotropin by hypothalamic cathepsin D. Gen. Biochem. 94: 181-184.

arutyunyan, A. A., Akopyan, T. N., Oganisyan, A. I., Galfayan, V. T. and Galoyan, A. A. (1980) Degradation of ACTH and $\beta$-lipotropin by hypothalamic cathepsin D. Voprosi Biochem. Mozga 14: 51-57.

AUSTEN, B. M. (1982) Isolation from pituitary granules and properties of a protease specific for consecutive basic residues. In: Peptides 1982: Synthesis, Structure and Function, pp. 493-496, RucH, D. H. and Gross, E. (eds) Pierce Chem. Comp., Rockford, Ill.

Austen, B. M. and Sмyтt, D. G. (1977a) Studies on limited proteolysis and degradation of lipotropin C-fragment. Biochem. Soc. Trans. 5: $1394-1397$.

Austen, B. M. and SMYTH, D. G. (1977b) Specific cleavage of lipotropin C-fragment by endopeptidases; evidence for a preferred conformation. Biochem. biophys. Res. Commun. 77: 86-94.

Austen, B. M. and SMYth, D. G. (1977c) The $\mathrm{NH}_{2}$-terminus of $\mathrm{C}$-fragment is resistant to the action of aminopeptidases. Biochem. biophys. Res. Commun. 76: 477-482.

Austen, B. M. and SMYTH, D. G. (1978) Distribution and properties of lipotropin activating proteases in rat brain. Proc. of the 2nd ESN Meeting, Göttingen, p. 460.

Austen, B. M., SMYTh, D. G. and SNELl, C. R. (1977a) $\gamma$-Endorphin, $\alpha$-endorphin and Met-enkephalin are formed extracellularly from $\mathrm{LPH}_{61-91}$. Nature 269: 619-621.

Austen, B. M., Smyth, D. G. and SNELl, C. R. (1977b) Studies on limited proteolysis and degradation of LPH $_{61-91}$. Biochem. Soc. Trans. 5: 1394.

Bachelot, I., WOLFSEN, A. R. and ODELL, W. D. (1977) Pituitary and plasma lipotropins: demonstration of the artifactual nature of $\beta$-MSH. J. clin. Endocr. Metab. 44: 939-946.

Bajusz, S., Barabás, É., SzÉll, E. and Bagdy, D. (1975) Peptide aldehyde inhibitors of the fibrinogen-thrombin reaction. In: Peptides: Chemistry, Structure and Biology, pp. 603-608, WaLter, R. and MeIENHOFER, J. (eds) Ann Arbor Science Publ., Ann Arbor.

Bajusz, S., Barabás, É., Tolnay, P., SzÉll, E. and Bagdy, D. (1978) Inhibition of thrombin and trypsin by tripeptide aldehydes: Int. J. Pept. Prot. Res. 12: 217-221.

Barát, E., Patthy, A. and Gráf, L. (1979) Action of cathepsin D on human $\beta$-lipotropin: a possible source of human " $\beta$-melanotropin". Proc. natn. Acad. Sci. U.S.A. 76: 6120-6123.

BÉgeot, M., Dubors, M. P. and Dubois, P. M. (1978) Immunologic localization of $\alpha$ - and $\beta$-endorphins and $\beta$-lipotropin in corticotropic cells of the normal and anencephalic fetal pituitaries. Cell Tiss. Res. 193: 413-422.

Bennett, H. P. J., Browne, C. A. and Solomon, S. (1983) $\alpha$-N-Acetyl- $\beta$-endorphin-(1-26) from the neurointermediate lobe of the rat pituitary: isolation, purification and characterization by high-performance liquid chromatography. Analyt. Biochem. 128: 121-129.

Benuck, M., Grynbaum, A. and Marks, N. (1978a) Breakdown of somatostatin and substance P by cathepsin D purified from calf brain by affinity chromatography. Brain Res. 143: 181-185.

Benuck, M., Grynbaum, A., COOPER, T. B. and MARKs, N. (1978b) Conversion of lipotropic peptides by purified cathepsin $\mathrm{D}$ of human pituitaries: release of $\gamma$-endorphin by cleavage of the Leu ${ }^{77}-\mathrm{Phe}^{78}$ bond. Neurosci. Lett. 10: 3-9. 
Berger, P. A., Watson, S. J., Akil, H., Elliot, G. R., Rubin, R. T., Pfefferbaum, A., Davis, Kl., Barchas, J. D. and LI, C. H. (1980) $\beta$-Endorphin and schizophrenia. Arch. gen. Psychiat. 37: 635-640.

Bertagna, X. Y., Stone, W. J., Nicholson, W. E., Mount, D. N. and OrTh, D. N. (1981) Simultaneous assay of immunoreactive $\beta$-lipotropin, $\gamma$-lipotropin, and $\beta$-endorphin in plasma of normal human subjects, patients with ACTH/lipotropin hypersecretory syndromes, and patients undergoing chronic hemodialysis. J. clin. Invest. 67: 124-133.

BiRK, Y. and $\mathrm{Li}, \mathrm{C}$. H. (1964) Isolation and properties of a new, biologically active peptide from sheep pituitary glands. J. biol. Chem. 239: 1048-1052.

Bloom, F., Battenberg, E., Rossier, J., Ling, N., Leppäluoto, J., Vargo, T. M. and Guillemin, R. (1977) Endorphins are located in the intermediate and anterior lobes of the pituitary gland, not in the neurohypophysis. Life Sci. 20: 43-48.

Bloomfield, G. A., Scott, A. P., Lowry, P. J., Gilkes, J. H. and Rees, L. H. (1974) A reappraisal of human $\beta$-MSH. Nature 252: 492-493.

Boucher, R., Asselin, J. and Genest, J. (1974) A new enzyme leading to the direct formation of angiotensin II. Circ. Res. 34, suppl. I: 203-209.

Bradbury, A. F., Smyth, D. G. and Snell, C. R. (1975) Biosynthesis of $\beta$-MSH and ACTH. In: Peptides: Chemistry, Structure, and Biology, pp. 609-615, WALTER, R. and MEIERHOFER, J. (eds) Ann Arbor Science Publ., Ann Arbor.

Bradbury, A. F., SMYth, D. G. and SNell, C. R. (1976a) Lipotropin: precursor to two biologically active peptides. Biochem. biophys. Res. Commun. 69: 950-956.

Bradbury, A. F., Smyth, D. G., Snell, C. R., Birdsall, N. J. M. and Hulme, E. C. (1976b) C-fragment of lipotropin has a high affinity for brain opiate receptors. Nature 260: 793-795.

Burbach, J. P. H. (1980) Proteolytic conversion of $\beta$-endorphin and oxytocin in rat brain. Doctoral Thesis, University of Utrecht.

Burbach, J. P. H. (1982) Neuropeptides and cerebrospinal fluid. Ann. clin. Biochem. 19: 269-277.

BURBACH, J. P. H. (1983) Local biotransformation of des-tyrosine- $y$-endorphin in brain studied by a push-pull technique and high-pressure liquid chromatography. Neurosci. Lett. 38, 281-285.

BurbaCH, J. P. H. and DE WIED, D. (1980) Adaptive behavior and endorphin biotransformation. In: Enzymes and Neurotransmitters in Mental Disease, pp. 103-114, Usdin, E., SourKes, T. L. and YoudiM, M. B. H. (eds) John Wiley and Sons, New York.

BURBACH, J. P. H. and DE WIED, D. (1981) Memory effects and brain proteolysis of neurohypophyseal hormones. In: Neurohypophyseal Peptide Hormones and Other Biologically Active Peptides, pp. 69-87, SCHLESINGER, D. M. (ed.) Elsevier/North-Holland Biomed. Press, Amsterdam.

Burbach, J. P. H. and DE Kloet, E. R. (1982) Proteolysis of $\beta$-endorphin in brain tissue. Peptides 3: 451-453.

Burbach, J. P. H. and DE WIED, D. (1982) Proteolytic conversion of $\beta$-endorphin into behaviourally active peptides. In: Neuronal Plasticity and Memory Formation, pp. 153-158, AJMONE MARSAN, C. and MATTHIES, H. (eds) IBRO Monograph Series, Vol. 9. Raven Press, New York.

Burbach, J. P. H. and Leboullee, J. L. M. (1983) Proteolytic conversion of arginine-vasopressin and oxytocin by brain synaptic membranes. Characterization of formed peptides and mechanisms of proteolysis. J. biol. Chem. 258: 1487-1494.

Burbach, J. P. H. and WIEGANT, V. M. (1983) Isolation and characterization of $\alpha$-endorphin and $\gamma$-endorphin from single human pituitary glands. FEBS Lett. 166, 267-272.

Burbach, J. P. H., Loeber, J. G., Verhoef, J., De Kloet, E. R., Van Ree, J. M. and DE Wied, D. (1979a) Schizophrenia and degradation of endorphins in cerebrospinal fluid. Lancet ii: $480-481$.

Burbach, J. P. H., Loeber, J. G., Verhoef, J., de Kloet, E. R. and DE Wied, D. (1979b) Biotransformation of endorphins by a synaptosomal plasma membrane preparation of rat brain and by human serum. Biochem. biophys. Res. Commun. 86: 1296-1303.

Burbach, J. P. H., Loeber, J. G., Verhoef, J., Wiegant, V. M., De Kloet, E. R. and De Wied, D. (1980a) Selective conversion of $\beta$-endorphin into peptides related to $\gamma$ - and $\alpha$-endorphin. Nature 283: 96-97.

Burbach, J. P. H., LOEBer, J. G., Verhoef, J. and DE KloEt, E. R. (1980b) $\beta$-Endorphin biotransformation in brain: formation of $\gamma$-endorphin by a synaptosomal plasma membrane associated endopeptidase distinct from cathepsin D. Biochem. biophys. Res. Commun. 92: 725-732.

Burbach, J. P. H., Schotman, P., Verhoef, J., De Kloet, E. R. and DE Wied, C. (1980c) Conversion of des-tyrosine- $\gamma$-endorphin by brain synaptic membrane associated peptidases: identification of generated peptide fragments. Biochem. biophys. Res. Commun. 97: 995-1004.

Burbach, J. P. H., De Kloet, E. R., Schotman, P. and DE WIED, D. (1981) Proteolytic conversion of $\beta$-endorphin by brain synaptic membranes: characterization of generated $\beta$-endorphin fragments and proposed metabolic pathway. J. biol. Chem. 256: 12463-12469.

Chan, J. S. D., Seidah, N. G., Ikeda, M., Gutkowske, J., Boucher, R., Genest, J. and Chrétien, M. (1981) Detection from rat pituitary of $\beta$-lipotropin and materials containing opiate-like activity by combined enzymatic radio-receptor assay. Can. J. Physiol. Pharmac. 59: 811-817.

Chang, T-L. and LoH, Y. P. (1983) Characterization of pro-opiocortin converting activity in rat anterior pituitary secretory granules. Endocrinology 112: 1832-1839.

Chang, T-L., Gainer, H., Russell, J. T. and Loh, Y. P. (1982) Proopiocortin-converting enzyme activity in bovine neurosecretory granules. Endocrinology 111: 1607-1614.

Chang, W-C., RaO, A. J. and LI, C. H. (1978) Rate of disappearance of $\mathrm{h}-\beta \mathrm{LPH}$ and $\beta$-endorphin in adult male rats as estimated by RIA. Int. J. Pept. Prot. Res. 11: 93-94.

Chang, W-C., Chung, D. and Li, C. H. (1980) Isolation and characterization of $\beta$-lipotropin and adrenocorticotropin from turkey pituitary glands. Int. J. Pept. Prot. Res. 15: 261-270.

Chappell, M. C., LoH, Y. P. and O'Donohue, T. L. (1982) Evidence for an opiomelanotropin acetyltransferase in the rat pituitary neurointermediate lobe. Peptides 3: 405-410.

ChrÉTIEN, M. and LI, C. H. (1967) Isolation, purification, and characterization of $\gamma$-lipotropic hormones from sheep pituitary glands. Can. J. Biochem. 45: 1163-1174. 
Chrétien, M. and LIs, M. (1978) Lipotropins: In: Hormonal Proteins and Peptides, Vol. 5, Lipotropins and Related Peptides, pp. 75-102, Li, C. H. (ed.) Academic Press, New York.

Chrétien, M., Lis, M., Gilardeau, C. and Benjannet, S. (1976a) In vitro biosynthesis of $\gamma$-lipotropic hormone. Can. J. Biochem. 54: 566-570.

Chrétien, M., Benjannet, S., Dragon, N., Seidah, N. G. and Lis, M. (1976b) Isolation of peptides with opiate activity from sheep and human pituitaries: relationship to beta-lipotropin. Biochem. biophys. Res. Commun. 72: $472-478$.

Chrétien, M., Benjannet, S., Gossard, F., Glanoulakis, C., Crine, P., Lis, M. and Seidah, N. G. (1979) From $\beta$-LPH to $\beta \mathrm{E}$ and 'pro-opiomelanocortin'. Can. J. Biochem. 57: 1111-1121.

Comb, M., Seeburg, P. H., Adelman, J., Eiden, L. and Herbert, E. (1982) Primary structure of the human Metand Leu-enkephalin precursor and its mRNA. Nature 295: 663-666.

Cox, B. M., Goldstein, A. and LI, C. H. (1976) Opioid activity of a peptide, $\beta$-lipotropin-(61-91), derived from $\beta$-lipotropin. Proc. natn. Acad. Sci. U.S.A. 73: 1821-1823.

Crine, P., Gianoulakis, C., Seidah, N. G., Gossard, F., Pezalla, P. D., Lis, M. and Chrétien, M. (1978) Biosynthesis of $\beta \mathrm{E}, \beta \mathrm{LPH}$ and a larger molecular weight precursor in rat pars intermedia. Proc. natn. Acad. Sci. U.S.A. 75: 4719-4723.

Crine, P., Gossard, F., Seidah, N. G., Blanchette, L., Lis, M. and Chrétien, M. (1979) Concomitant synthesis of $\beta$-endorphin and $\alpha \mathrm{MSH}$ from two forms of pro-opiomelanocortin in the rat pars intermedia. Proc. natn. Acad. Sci. U.S.A. 76: 5085-5089.

Davis, T. P., Schoemaker, H., Hynes, M. R., Galligan, J. J., Yamamura, H. I. and Burks, T. F. (1983) Endorphin metabolism in brain and gut: regional specificity. Fedn Proc. 42: 499.

Deakin, J. F. W., Doströvsky, J. O. and Smyth, D. G. (1980) Influence of N-terminal acetylation and C-terminal proteolysis on the analgesic activity of $\beta$-endorphin. Biochem. J. 189: 501-506.

Demassieux, S., Boucher, R., Grisé, C. and Genest, J. (1976) Purification and characterization of tonin. Can. J. Biochem. 54: 788-795.

Desbuquois, B., Krug, F. and Cuatrecasas, P. (1974) Inhibitors of glucagon inactivation: effect on glucagonreceptor interactions and glucagon-stimulated adenylate cyclase activity in liver cell membranes. Biochim. Biophys. Acta 343: 101-120.

DE WIED, D. and Jolles, J. (1982) Neuropeptides derived from pro-opiocortin: behavioral, physiological, and neurochemical effects. Physiol. Rev. 62: 976-1059.

DE WIED, D. (1978) Psychopathology as a neuropeptide dysfunction. In: Characteristics and Function of Opioids, pp. 113-122, VAN ReE, J. M. and Terenius, L. (eds) Elsevier/North-Holland, Amsterdam.

de Wied, D., Kovács, G. L., Bohus, B., Van Ree, J. M. and Greven, H. M. (1978) Neuroleptic activity of the neuropeptide $\beta \mathrm{LPH}_{62-77}$ (dT $\gamma \mathrm{E}$ ). Eur. J. Pharmac. 49: 427-436.

DE Wied, D., VAN ReE, J. M. and Greven, H. M. (1980) Neuroleptic-like activity of peptides related to [des-tyr'] ${ }^{1}$-endorphin: structure activity studies. Life Sci. 26: 1575-1579.

DOCHER TY, K. and SteINER, D. F. (1982) Post-translational proteolysis in polypeptide hormone biosynthesis. $A$. Rev. Physiol. 44: 624-638.

Docherty, K., Carroll, R. J. and Steiner, D. F. (1982) Conversion of proinsulin to insulin: involvement of a 31,500 molecular weight thiol protease. Proc. natn. Acad. Sci. U.S.A. 79: 4613-4617.

Docherty, K., Carroll, R. J. and Steiner, D. F. (1983) Identification of a 31,500 molecular weight islet cell protease as cathepsin B. Proc. natn. Acad. Sci. U.S.A. 80: 3245-3249.

Dorsa, D. M., Majumdar, L. A. and Chapman, M. B. (1981) Regional distribution of gamma- and beta-endorphin-like peptides in the pituitary and brain of the rat. Peptides 2: 71-77.

Dorsa, D. M., Chapman, M. B. and Baskin, D. G. (1982) Gamma-endorphin-like peptides in pituitary tissue: evidence for their existence in vivo. Peptides 3: 455-460.

Drouin, J. and GoOdman, H. M. (1980) Most of the coding region of rat ACTH- $\beta$-LPH precursor gene lacks intervening sequences. Nature 288: 610-613.

EIPPER, B. A. and MAINS, R. E. (1978) Existence of a common precursor to ACTH and endorphin in the anterior and intermediate lobe of the rat pituitary. J. supramolec. Struct. 8: 247-262.

EIPPER, B. A. and MAINS, R. E. (1980) Structure and biosynthesis of pro-adrenocorticotropin/endorphin and related peptides. Endocr. Rev. 1: 1-27.

EIPPER, B. A. and MAINS, R. E. (1981) Further analysis of post-translational processing of $\beta$-endorphin in rat intermediate pituitary. J. biol. Chem. 256: 5689-5695.

Evangelista, R., RAY, P. and Lewis, R. V. (1982) A "trypsin-like" enzyme in adrenal chromaffin granules: a proenkephalin processing enzyme. Biochem. biophys. Res. Commun. 106: 895-902.

Evans, C. J., Weber, E. and Barchas, J. D. (1981) Isolation and characterization of $\alpha-N$-acetyl- $\beta$-endorphin (1-26) from the rat posterior/intermediate pituitary lobe. Biochem. biophys. Res. Commun. 102: 897-904.

Fletcher, D. J., Noe, B. D., Bauer, G. E. and Quigley, J. P. (1980) Characterization of the conversion of a somatostatin precursor to somatostatin by islet secretory granules. Diabetes 29: 593-599.

Fletcher, D. J., Quigley, J. P., Bauer, G. E. and NoE, B. D. (1981) Characterization of proinsulin- and proglucagon converting activities in isolated islet secretory granules. J. Cell Biol. 90: 312-322.

Foley, K. M., Kourides, I. A., Inturrisi, G. E., Kaiko, R. F., Zaroulis, C. G., Posner, J. B., Houde, R. W. and LI, C. H. (1979) $\beta$-Endorphin: analgesic and hormonal effects in humans. Proc. natn. Acad. Sci. U.S.A. 76: $5377-5381$.

Fukata, J., NaKai, Y. and ImURa, H. (1979) Presence of immunoreactive $\alpha$-endorphin in rat pituitary gland. Life Sci. 25: 541-546.

GeIsow, M. J. (1978) Polypeptide secondary structure may direct the specificity of prohormone conversion. FEBS Lett. 87: 111-114.

Geisow, M. J. and SMYTH, D. G. (1977a) Lipotropin C-fragment has a COOH-terminal sequence with high intrinsic resistance to the action of exopeptidases. Biochem. biophys. Res. Commun. 75: 625-629.

Geisow, M. J. and SмYTH, D. G. (1977b) Preparation and properties of lipotropin C-fragment with anionic substituents attached to the lysine residues. FEBS Lett. 81: 431-434. 
Gerner, R. H., Sharp, B. and Catlin, D. H. (1982) Peripherally administered $\beta$-endorphin increases cerebrospinal fluid endorphin immunoreactivity. J. clin. Endocr. Metab. 55: 358-360.

GIAGNONI, G., SABOL, S. L. and NiREnBERG, M. (1977) Synthesis of opiate peptides by a clonal pituitary tumor cell line. Proc. natn. Acad. Sci. U.S.A. 74: 2259-2263.

Gibaldi, M. and Perrier, D. (1975) Drugs and the Pharmaceutical Sciences, Vol. 1, Pharmacokinetics, Marcel Dekker Inc., New York and Basel.

Gilardeau, C. and Chrétien, M. (1972) Complete amino acid sequence of $\beta$-lipotropic hormones ( $\beta$-LPH). In: Chemistry and Biology of Peptides, pp. 609-611, MeIEnHofer, J. (ed) Ann Arbor Sci. Publ., Ann Arbor.

GLEMBOTSKI, C. C. (1982a) Acetylation of $\alpha$-melanotropin and $\beta$-endorphin in the rat intermediate pituitary. J. biol. Chem. 257: 10493-10500.

Glembotski, C. C. (1982b) Characterization of the peptide acetyl-transferase activity in bovine and rat intermediate pituitaries responsible for the acetylation of $\beta$-endorphin and $\alpha$-melanotropin. $J$. biol. Chem. 257: $10501-10509$

Gráf, L. (1976) Fragmentation of porcine $\beta$-lipotropic hormone with plasmin. Acta Biochim. Biophys. Acad. Sci. Hung. 11: 267-277.

GrÁf, L. and LI, C. H. (1973) Action of plasmin on ovine $\beta$-LPH: revision of the carboxyl terminal sequence. Biochem. biophys. Res. Commun. 53: 1304-1309.

GráF, L. and KeNESSEY, A. (1976) Specific cleavage of a single peptide bond (77-78) in $\beta$ LPH by a pituitary endopeptidase. FEBS Lett. 69: 255-260.

GrÁf, L. and HollósI, M. (1980) Substrate conformation directs selective enzymic cleavage of $\beta$-lipotropin into $\beta$-endorphin. Biochem. biophys. Res. Commun. 93: 1089-1093.

GrÁF, L. and KENESSEY, A. (1981) Characterization of proteinases involved in the generation of opioid peptides from $\beta$-lipotropin. In: Hormonal Proteins and Peptides, Vol. X, pp. 35-63, LI, C. H. (ed.) Academic Press, New York.

Gráf, L., Barat, E., Patthy, A. and CSEH, G. (1974) Isolation and properties of a new lipolytic peptide from human pituitary glands. Arch. Biochem. Biophys. 161: 211-215.

Gráf, L., Barat, E. and PATthy, A. (1976a) Isolation of a COOH-terminal $\beta$-lipotropin fragment (residues 61-91) with morphine-like analgesic activity from porcine pituitary glands. Acta Biochim. Biophys. Acad. Sci. Hung. 11: 121-122.

Gráf, L., Ronai, A. Z., Bajusz, S., Cseh, G. and Székely, J. (1976b) Opioid agonist activity of $\beta$-LPH fragments: a possible biological source of morphine-like substances in the pituitary. FEBS Lett. 64: $181-185$.

Gráf, L., Kenessey, A., Berzétei, J. and Ronal, A. Z. (1977) Demonstration of $\beta$-LPH activating enzyme in porcine pituitary. Biochem. biophys. Res. Commun. 78: 1114-1123.

Gráf, L., Kenessey, A. and MaKara, G. B. (1978a) Endorphins and/or artefacts: characterization of some pituitary proteinases involved in the generation of opioid peptides from $\beta$ LPH. In: Endorphins ' 78 , pp. 127-137, Gráf, L., Palkovits, M. and Ronai, A. Z. (eds) Akadémiai Kiadó, Budapest.

Gráf, L., Kenessey, A., Ronal, A. Z., Patthy, A., Székely, J. I. and Bajusz, S. (1978b) Release and biodegradation of endorphins in the pituitary and the brain. Mammalian Biochem. 89: 407-417.

Gráf, L., Kenessey, A., Bajusz, S., Patthy, A., Ronal, A. Z. and Berzétei, I. (1979a) Proteolytic processing in the biosynthesis and metabolism of endorphins. In: Endorphins in Mental Health Research, pp. 189-203, Usdin, E., BunneY, JR., W. E. and KLine, N. S. (eds) Macmillan, New York.

Gráf, L., Kenessey, A., Patthy, A., Grynbaum, A., Marks, N. and Lajtha, A. (1979b) Cathepsin D generates $\gamma \mathrm{E}$ from $\beta \mathrm{E}$. Arch. Biochem. Biophys. 193: 101-109.

Gramsch, C., Kleber, G., Höllt, V., Pasi, A., Mehraein, P. and Herz, A. (1980) Pro-opiocortin fragments in human and rat brain: $\beta$-endorphin and $\alpha$-MSH are the rredominant peptides. Brain Res. 192: 109-119.

Grynbaum, A., Kastin, A. J., Coy, D. H. and Marks, N. (1977) Breakdown of enkephalin and endorphin analogs by brain extracts. Brain Res. Bull. 2: 479-484.

Gubler, U., Seeburg, P., Hoffman, B. J., Gage, L. P. and Udenfriend, S. (1982) Molecular cloning establishes proenkephalin as precursor of enkephalin-containing peptides. Nature 295: 206-208.

Guillemin, R., LiNg, N. and BuRgus, R. (1976) Endorphines, peptides d'origine hypothalamique et neurohypophysaire à activité morphinomimétique. Isolement et structure moléculaire d' $\alpha$-endorphine. C.r. Acad. Sci. (Paris) 282 Ser. D: 783-785.

Habener, J. F., Chang, H. T. and Potts, J. T. (1977) Enzymatic processing of proparathyroid hormone by cell-free extracts of parathyroid glands. Biochemistry 16: 3910-3917.

HARRIS, J. I. and LeRNer, A. B. (1957) Amino acid sequence of the $\alpha$-melanocyte-stimulating hormone. Nature 179: $1346-1347$

HAR TSUCK, J. A. and LiPSCOMB, W. N. (1971) Carboxypeptidase A. In: The Enzymes, Vol. III, pp. 1-56, Boyer, P. D. (ed.) Academic Press, New York.

Heinrich, G. and Todd, P. (1979) Pituitary enzyme which splits pro-insulin. In: Peptides '79, pp. 173-176, Gross E. and Meienhofer, J. (eds) Pierce Chem. Comp., Rockford, Ill.

Herbert, E., Roberts, J., Phillips, M., Allen, R., Hinman, M., Budarf, M., Policastro, P. and Rosa, P. (1980) Biosynthesis, processing, and release of corticotropin, $\beta$-endorphin, and melanocyte stimulating hormone in pituitary cell culture systems. In: Frontiers in Neuroendocrinology, Vol. 6, pp. 67-102, MARTINI, L. and GanONG, W. F. (eds) Raven Press, New York.

Hersch, L. B., Smith, T. E. and McKelvy, J. F. (1980) Cleavage of endorphins to des-Tyr endorphins by homogeneous bovine brain aminopeptidase. Nature 286: 160-162.

HerSCH, L. B. and MCKelvY, J. F. (1981) An aminopeptidase from bovine brain which catalyzes the hydrolysis of enkephalin. J. Neurochem. 36: 171-178.

HORSTHEMKE, B. and BAUER, K. (1981) Chymotryptic-like hydrolysis of luliberin (LH-RF) by an adenohypophyseal enzyme of high molecular weight. Biochem. biophys. Res. Commun. 103: 1322-1328.

Houghten, R. A., SWANN, R. W. and LI, C. H. (1980) $\beta$-Endorphin: stability, clearance behaviour, and entry 
into the central nervous system after intravenous injection of the tritiated peptide in rats and rabbits. Proc. natn. Acad. Sci. U.S.A. 77: 4588-4591.

Hsi, K. L., Seidah, N. G., Lu, G. L. and Chrétien, M. (1981) Reinvestigation of the $N$-terminal amino acid sequence of $\beta$-lipotropin from human pituitary glands. Biochem. biophys. Res. Commun. 103: 1329-1335.

Hudson, P., Haley, J., Crouk, M., Shine, J. and Niall, H. (1981) Molecular cloning and characterization of cDNA sequences coding for rat relaxin. Nature 291: 127-131.

Hughes, J., Smith, T. W., Kosterlitz, H. W., Fothergill, L. A., Morgan, B. A. and Morris, H. R. (1975) Identification of two related pentapeptides from the brain with potent opiate agonist activity. Nature 258: $577-579$.

Jegou, S., Tonon, M. Ch., Leboulenger, F., Delarue, C., Vaudry, H. and Ling, N. (1978) Radioimmunoassay for $\gamma$-endorphin. Biochem. biophys. Res. Commun. 83: 201-208.

Jegou, S., Lepine, J., Cote, J., Dupont, A., Tonon, M. Ch., Pelletier, G., Vaudry, H. and Labrie, F. (1979) Effect of adrenalectomy and glucocorticoid treatment upon ACTH, $\alpha$-MSH, $\beta$-MSH, $\beta$-LPH, $\beta$-endorphin and $\gamma$-endorphin-like immunoreactivities in the anterior lobe of the pituitary. In: Radioimmunology Proc. int. Symp. 4, pp. 45-51, Bizolon, C. A. (ed.). Elsevier/North-Holland, Amsterdam.

Johnson, R. G. and SCARPA, A. (1976) Internal pH of isolated chromaffin vesicles. J. biol. Chem. 251: 2189-2191.

Jörnvall, H., Carlquist, M., Kwauk, S., Otte, S. C., Macintosh, C. H. S., Brown, J. C. and Mutt, V. (1981) Amino acid sequence and heterogeneity of gastric inhibitory polypeptide (GIP). FEBS Lett. 123: 205-210.

Kawauchi, H., TuboKawa, M. and Muramoto, K. (1979) Isolation and primarily structure of endorphin from salmon pituitary glands. Biochem. biophys. Res. Commun. 88: 1249-1254.

Kawauchi, H., Chung, D. and LI, C. H. (1980a) Isolation and characterization of $\beta$-lipotropin from fin whale pituitary glands. Int. J. Pept. Prot. Res. 15: 171-176.

Kawauchi, H., Tsubokawa, M., Kanerawa, A. and Kitagawa, H. (1980b) Occurrence of two different endorphins in the salmon pituitary. Biochem. biophys. Res. Commun. 92: 1278-1288.

Kenessey, A., Gráf, L. and Palkovits, M. (1977) Regional distribution of $\beta$-LPH converting enzymes in rat pituitary and brain. Brain Res. Bull. 2: 247-250.

Kenessey, A., Gráf, L., Páldi-Haris, P. Hermann, I. and Borvendég, J. (1978) Studies on the subcellular localization and purification of $\beta$ LPH-activating enzyme of the pituitary. In: Endorphins '78, pp. 139-154, Gráf, L., Palkovtis, M. and Ronai, A. Z. (eds) Akadémiai Kiadó, Budapest.

Kenessey, A., Páldi-Haris, P., Makara, G. B. and Gráf, L. (1979) Trypsin-like activity of rat anterior pituitary in relation to secretory activity. Life Sci. 25: 437-444.

KNIGHT, M. and KLEE, W. A. (1979) Enkephalin generating activity of rat brain endopeptidases. J. biol. Chem. 254: $10426-10430$.

Knight, M., Plotkin, C. and Tamminga, C. A. (1982) Brain endopeptidase generates enkephalin from striatal precursors. Peptides 3: 461-468.

Koida, M., Aono, J., Takenaga, K., Yoshimoto, T., Kimura, T. and Sakakibara, S. (1979) A novel enzyme in rat brain converting $\beta$-endorphin into methionine enkephalin: affinity chromatography and specificity. J. Neurochem. 33: 1233-1237.

LAND, H., SCHÜtZ, G., SCHMAle, H. and Richter, O. (1982) Nucleotide sequences of cloned cDNA encoding bovine arginine vasopressin-neurophysin II precursor. Nature 295: 299-303.

Lazure, C., Seidah, N. G., Pélaprat, D. and Chrétien, M. (1983) Proteases and post-translational processing of prohormones: a review. Can. J. Biochem. 61, 501-515.

LEE, T. H. and LEE, M. S. (1982) Characterization of a microsomal endopeptidase which is capable of processing corticotropin- $\beta$-lipotropin common precursor. Proc. 64th A. Meeting Endocr. Soc., abstr. 597.

Legon, S., Glover, D. M., Hughes, J., Lowry, P. J., Rigby, P. W. J. and Watson, C. J. (1982) The structure and expression of the pre-proenkephalin gene. Nucleic Acids Res. 10: 7905-7918.

Lehman, H., NAIR, N. P. V. and KLINE, N. S. (1979) $\beta$-Endorphin and naloxone in psychiatric patients: clinical and biological effects. Am. J. Psychiat. 136: 762-766.

Lerner, A. B., Shizume, K. and Bunding, I. (1954) The mechanism of endocrine control of melanin pigmentation. J. clin. Endocr. Metab. 14: 1463-1490.

LI, C. H. (1957) Hormones of the anterior pituitary gland, part II, melanocyte-stimulating and lactogenic hormones. Adv. Protein Chem. 12: 269-317.

LI, C. H. (1964) Lipotropin, a new active peptide from pituitary glands. Nature 201: 924.

LI, C. H. and ChUNG, D. (1976) Isolation and structure of an untriakontapeptide with opiate activity from camel pituitary glands. Proc. natn. Acad. Sci. U.S.A. 73: 1145-1148.

Li, C. H., Barnafi, L., Chrétien, M. and Chung, D. (1965) Isolation and amino acid sequence of $\beta$-LPH from sheep pituitary glands. Nature 208: 1093-1094.

Li, C. H., TAN, L. and CHUNG, D. (1977) Isolation and primary structure of $\beta$-endorphin and $\beta$-lipotropin from bovine pituitary glands. Biochem. biophys. Res. Commun. 77: 1088-1093.

Li, C. H., Ng, T. B., Yamashiro, D., Chung, D., Hammonds, R. G. and Tseng, L-F. (1981) $\beta$-Endorphin: isolation, amino acid sequence and synthesis of the hormone from horse pituitary glands. Int. J. Pept. Prot. Res. 18: 242-248.

LiNDBERG, I., YANG, H. -Y. T. and CostA, E. (1982a) An enkephalin-generating enzyme in bovine adrenal medulla. Biochem. biophys. Res. Commun. 106: 186-193.

LindBerG, I., YANG, H. -Y. T. and Costa, E. (1982b) Characterization of a partially purified trypsin-like enkephalin-generating enzyme in bovine adrenal medulla. Life Sci. 31: 1713-1716.

Ling, N., BuRgus, R. and GUILlemin, R. (1976) Isolation, primary structure and synthesis of $\alpha$-endorphin and $\gamma$-endorphin, two peptides of hypothalamic-hypophyseal origin with morphinomimetic activity. Proc. natn. Acad. Sci. U.S.A. 73: 3942-3946.

LiotTA, A. S. and Krieger, D. T. (1980) In vitro biosynthesis and comparative posttranslational processing 
of immunoreactive precursor corticotropin $/ \beta$-endorphin by human placental and pituitary cells. Endocrinology 106: 1504-1511.

Liotta, A. S., Li, C. H., Schussler, G. C. and Krieger, D. T. (1978) Comparative metabolic clearance rate, volume of distribution and plasma half-life of h- $\beta$ LPH and ACTH. Life Sci. 23: 2323-2330.

Liotta, A. S., GildersleEve, D., Brownstein, M. J. and Krieger, D. T. (1979) Biosynthesis in vitro of immunoreactive $31 \mathrm{~K}$ ACTH $/ \beta$ E like material by bovine hypothalamus. Proc. natn. Acad. Sci. U.S.A. 76: $1448-1451$.

Liotta, A. S., Landes, C., MCKelvy, J. F. and Krieger, D. T. (1980) Biosynthesis of precursor corticotropin/endorphin-, corticotropin-, $\alpha$-melanotropin-, $\beta$-lipotropin-, and $\beta$-endorphin-like material by cultured neonatal rat hypothalamic neurons. Proc. natn. Acad. Sci. U.S.A. 77: 1880-1884.

Liotta, A. S., Yamaguchi, H. and Krieger, D. T. (1981) Biosynthesis and release of $\beta$-endorphin-, $N$-acetyl- $\beta$-endorphin-, $\beta$-endorphin-(1-27), and $N$-acetyl- $\beta$-endorphin-(1-27)-like peptides by rat pituitary neurointermediate lobe: $\beta$-endorphin is not further processed by anterior lobe. J. Neurosci. 1: 585-595.

LIs, M. (1982) Physiological effects of $\beta$-LPH. Ph.D. Thesis, McGill University.

Lissitsky, J-C., Morin, O., Dupont, A., labrie, F., Seidah, N. G., Chrétien, M., Lis, M. and Coy, D. H. (1978) Content of $\beta$-LPH and its fragments (including endorphins) in anterior and intermediate lobes of the bovine pituitary gland. Life Sci. 22: 1715-1722.

LOEBER, J. G. and VerHOEF, J. (1981) High-pressure liquid chromatography and radioimmunoassay for the specific and quantitative determination of endorphins and related peptides. In: Methods in Enzymology, Vol. 73, pp. 261-274, Colowick, S. P. and Kaplan, N. O. (eds) Academic Press, New York.

Loeber, J. G., Verhoef, J., Burbach, J. P. H. and WitTer, A. (1979) Combination of high pressure liquid chromatography and radioimmunoassay is a powerful tool for the specific and quantitative determination of endorphins and related peptides. Biochem. biophys. Res. Commun. 86: 1288-1295.

LoH, H. H., Tseng, L. F., WEI, E. and LI, C. H. (1976) $\beta$-Endorphin is a potent analgesic agent. Proc. natn. Acad. Sci. U.S.A. 73: 2895-2898.

LOH, Y. P. and GAINER, H. (1978) The role of glycosylation on the biosynthesis, degradation and secretion of the ACTH $/ \beta$ LPH common precursor and its peptide products. FEBS Lett. 96: 269-273.

LOH, Y. P. and GaINER, H. (1979) The role of carbohydrate in the stabilization, processing, and packaging of the glycosylated adrenocorticotropin-endorphin precursor in toad pituitaries. Endocrinology 105: 474-487.

LOH, Y. P. and GAINER, H. (1982a) Characterization of pro-opiocortin-converting activity in purified secretory granules from rat pituitary neurointermediate lobe. Proc. natn. Acad. Sci. U.S.A. 79: 108-112.

LoH, Y. P. and GaINER, H. (1982b) Processing of normal and non-glycosylated forms of toad pro-opiocortin by rat intermediate (pituitary) lobe pro-opiocortin converting enzyme activity. Life Sci. 31: 3043-3050.

LoH, Y. P. and Chang, T. L. (1982) Pro-opiocortin converting activity in rat intermediate and neural lobe secretory granules. FEBS Lett. 137: 57-62.

Loh, Y. P., Gritsch, H. A. and ChanG, T. L. (1982) Pro-opiocortin processing in the pituitary: a model for neuropeptide biosynthesis. Peptides 3: 397-404.

Lohmar, P. and LI, C. H. (1967) Isolation of bovine $\beta$-lipotropic hormone. Biochim. Biophys. Acta 147: 381-383.

MacGregor, R. R., Hamilton, J. W., Shofstall, R. E. and Cohn, D. V. (1979a) Isolation and characterization of porcine parathyroid cathepsin B. J. biol. Chem. 254: 4423-4427.

MacGregor, R. R., Hamilton, J. W., Kent, G. N., Shofstall, R. E. and Cohn, D. V. (1979b) The degradation of proparathormone by parathyroid and liver cathepsin B. J. biol. Chem. 254: 4428-4433.

MAINS, R. E. and EIPPER, B. A. (1978a) Coordinate synthesis of corticotrophins and endorphins by mouse pituitary tumor cells. J. biol. Chem. 253: 651-654.

MAINS, R. E. and EIPPER, B. A. (1978b) Studies on the common precursor to ACTH and endorphin. In: Endorphins' 78, pp. 79-126, GRÀF, L., PALKovits, M. and RonAI, A. Z. (eds) Akadémiai Kiadó, Budapest.

MAINS, R. E. and EIPPER, B. A. (1979) Synthesis and secretion of ACTH's, MSH's and endorphins by rat intermediate lobe pituitary cells. J. biol. Chem. 254: 7885-7894.

MAINS, R. E. and EIPPER, B. A. (1981) Differences in the post-translational processing of $\beta$-endorphin in rat anterior and intermediate pituitary. J. biol. Chem. 256: 5683-5688.

Mains, R. E., Eipper, B. A. and Ling, N. (1977) Common precursor to corticotropins and endorphins. Proc. natn. Acad. Sci. U.S.A. 74: 3014-3018.

Margioris, A. N., Liotta, A. S., Vaudry, H., Bardin, W. and Krieger, D. T. (1983) Characterization of immunoreactive pro-opiomelanocortin-related peptides in rat testes. Endocrinology 113: 663-671.

MARKS, N. (1978) Biotransformation and degradation of corticotropins, lipotropins and hypothalamic peptides. In: Frontiers in Neuroendocrinology, Vol. 5, pp. 329-377, Ganong, W. F. and MarTiNI, L. (eds) Raven Press, New York.

Marks, N., Grynbaum, A. and Neidle, A. (1977) On the degradation of enkephalins and endorphins by rat and mouse brain extracts. Biochem. biophys. Res. Commun. 74: 1552-1559.

Marks, N., Kastin, A. J., Stern, F. and Coy, D. H. (1978) Metabolism of potent enkephalin analogs (FK33-824, D-Ala ${ }^{2}$, pentafluorophenyl-alanine-4-enkephalinamide and a dimer of D-Ala ${ }^{2}$-enkephalinamide) and D-amino acid substituted derivatives of human $\beta$-endorphin. Brain Res. Bull. 3: 687-690.

Marks, N., SuHar, A. and BenUCK, M. (1980) Breakdown of opiate peptides by brain cathepsins and dipeptidyl carboxypeptidase. In: Neural Peptides and Neuronal Communication, pp. 205-217, Costa, E. and Trabucchi, M. (eds) Raven Press, New York.

Merin, M., Höllt, V., Przewlocki, R. and Herz, A. (1980) Cow permeation of systemically administered human $\beta$-endorphin into rabbit brain measured by radioimmunoassays differentiating human and rabbit $\beta$-endorphin. Life Sci. 27: 281-289.

Mizuno, K., Miyata, A., Kangawa, K. and Matsuo, H. (1982) A unique proenkephalin-converting enzyme purified from bovine adrenal chromaffin granules. Biochem. biophys. Res. Commun. 108: 1235-1242.

Nakanishi, S., Inoue, A., Kita, T., Nakamura, M., Chang, A. C. Y., Cohen, S. N. and Numa, S. (1979) 
Nucleotide sequence of cloned cDNA for bovine corticotropin- $\beta$-lipotropin precursor. Nature 278: $423-427$.

Naudé, R. J., Chung, D., Li, C. H. and Oelofsen, W. (1981a) $\beta$-Endorphin: primary structure of the hormone from the ostrich pituitary gland. Biochem. biophys. Res. Commun. 98: 108-114.

Naudé, R. J., Chung, D., Li, C. H. and Oelofsen, W. (1981b) $\beta$-Lipotropin: primary structure of the hormone from ostrich pituitary gland. Int. J. Pept. Prot. Res. 18: 138-147.

NG, T. B., Chung, D. and $\mathrm{Ll}, \mathrm{C}$. H. (1982) Isolation and properties of $\beta$-endorphin-(1-27)-like peptide from bovine brains. Int. J. Pept. Prot. Res. 19: 343-347.

Nicolas, P., Bewley, T. A., Gráf, L. and Li, C. H. (1981) $\beta$-Endorphin: demonstration of a tertiary structure in aqueous solution. Proc. natn. Acad. Sci. U.S.A. 78: 7290-7293.

Noda, M., Furutani, Y., Takahashi, H., Toyosato, M., Hirose, T., Inayama, S., Nakanishi, S. and Numa, S. (1982a) Cloning and sequence analysis of cDNA for bovine adrenal preproenkephalin. Nature 295 : 202-206.

Noda, M., Teranishi, Y., Takahashi, H., Toyosato, M., Notake, M., Nakanishi, S. and Numa, S. (1982b) Isolation and structural organization of the human preproenkephalin gene. Nature 297: 431-434.

Notake, M., Tobimatsu, T., Watanabe, Y., Takahashi, H., Mishina, M. and Numa, S. (1983) Isolation and characterization of the mouse corticotropin- $\beta$-lipotropin precursor gene and a related pseudogene. FEBS Lett. 156: 67-71.

O'Donohue, T. L. (1983) Identification of endorphin acetyltransferase in rat brain and pituitary gland. J. biol. Chem. 258: $2163-2167$.

Opmeer, F. A., Loeber, J. G. and Van Ree, J. M. (1980) Altered levels of $\beta$-endorphin fragments after chronic morphine treatment of guinea-pig ileum in vitro and in vivo. Life Sci. 27: 2393-2400.

OpmeEr, F. A., Burbach, J. P. H., Wiegant, V. M. and VAN ReE, J. M. (1982) $\beta$-Endorphin proteolysis by guinea-pig ileum myenteric plexus membranes: increased $\gamma$-endorphin turnover after chronic exposure to morphine. Life Sci. 31: 323-328.

Orlowski, M., Michaud, CH. and WILK, S. (1980) Generation of methionine- and leucine-enkephalin from precursor molecules by cation-sensitive neutral endopeptidase of bovine pituitary. Biochem. biophys. Res. Commun. 94: 1145-1153.

Palmour, R. M., Ervin, F. R., Chang, J-K. and Fong, B. (1978) In vitro degradation of synthetic Met ${ }^{5}-\beta$ E and Leu ${ }^{5}-\beta$ E. In: Characteristics and Function of Opioids, pp. 283-284, VAN ReE, J. M. and Terenius, L. (eds) Elsevier/North-Holland, Amsterdam.

Pankov, Y. A. (1973) Isolation of bovine $\beta$-lipotropin. Vop. Med. Khim. 19: 330-332.

Patthy, A., Gráf, L., Kenessey, A., Székely, J. I. and Bajusz, S. (1977) Effect of bacitracin on the biodegradation of $\beta$-endorphin. Biochem. biophys. Res. Commun. 79: 254-259.

PeACH, M. J. (1977) Renin-angiotensin system: biochemistry and mechanism of action. Physiol. Rev. 57: $313-370$.

Pedigo, N. W., Schoemaker, H., Ragan, P., Berens, E. S., Ling, N. C. and Yamamura, H. I. (1981) Neuroleptic-like activity of des-tyrosine- $\gamma$-endorphin $\left(\beta-\mathrm{LPH}_{62-77}\right)$ : possible mediation by an active metabolite $\beta$ - $\mathrm{LPH}_{66-77}$. Psychopharmac. Bull. 17: 147-151.

Pezalla, P. D., Lis, M., Seidah, N. G. and Chrétien, M. (1978) Lipotropin, $\beta$ MSH and $\beta$ E: in vivo catabolism and entry into CSF. J. Can. Sci. Neurol. 5: 183-188.

PICKeRING, B. T. and Li, C. H. (1963) On the properties of human $\beta$-melanocyte-stimulating hormones. Biochim. biophys. Acta 74: 156-157.

Powers, C. A. and NasjletTI, A. (1983) A kininogenase resembling glandular kallikrein in the rat pituitary pars intermedia. Endocrinology 112: 1194-1200.

Press, E. M., Porter, R. R. and Cebra, J. (1960) The isolation and properties of a proteolytic enzyme, cathepsin D, from bovine spleen. Biochem. J. 74: 501-514.

Reid, R. L., Hoff, J. D., YeN, S. S. C. and LI, C. H. (1981) Effects of exogenous $\beta_{\mathrm{b}}$-endorphin on pituitary hormone secretion and its disappearance rate in normal human subjects. J. clin. Endocr. Metab. 52: 1179-1184.

Reith, M. E. A. and Neidle, A. (1981) Breakdown and fate of ACTH and MSH. Pharmac. Ther. 12: 449-461.

Roberts, J. L., Phillips, M., Rosa, P. A. and Herbert, E. (1978) Steps involved in the processing of common precursor forms of ACTH and $\beta$-E in cultures of mouse pituitary cells. Biochemistry 17: 3609-3618.

Rossier, J., BAYON, A., VARGo, T. M. and LING, M. (1977) Radioimmunoassay of brain peptides: evaluation of a methodology for the assay of $\beta$-endorphin and enkephalin. Life Sci. 21: 847-852.

Rubinstein, M., StEIN, S. and UdENFrIEND, S. (1977) Isolation and characterization of the opioid peptides from rat pituitary: $\beta$-endorphin. Proc. natn. Acad. Sci. U.S.A. 74: 4969-4972.

Russel, J. T. and Holz, R. W. (1981) Measurement of $\Delta \mathrm{pH}$ and membrane potential in isolated neurosecretory vesicles from bovine neurohypophyses. J. biol. Chem. 256: 5950-5953.

SABOL, S. L. (1978) Regulation of endorphin production by glucocorticoids in cultured pituitary tumor cells. Biochem. biophys. Res. Commun. 82: 560-567.

SABoL, S. L. (1980) Storage and secretion of $\beta$-endorphin and related peptides by mouse pituitary tumor cells: regulation by glucocorticoids. Arch. Biochem. Biophys. 203: 37-48.

SCHACHTER, M. (1980) Kallikreins (Kininogenases)-A group of serine proteases with bioregulatory actions. Pharmac. Rev. 31: 1-17.

Schomaker, H., Davis, T. P., Pedigo, N. W., Chen, A., Berens, E. S., Ragan, P., Ling, N. C. and YAMAMURA, H. I. (1982) Identification of $\beta$-endorphin-(6-17) as the principal metabolite of des-tyrosine$\gamma$-endorphin $(\mathrm{DT} \gamma \mathrm{E})$ in vitro and assessment of its activity in neurotransmitter receptor binding assays. Eur. J. Pharmac. 81: 459-468.

Scott, A. P. and Lowry, P. J. (1974) Adrenocorticotrophic and melanocyte-stimulating peptides in the human pituitary. Biochem. J. 139: 593-602.

Seidah, N. G., Lis, M., Gianoulakis, C., Routhier, R., Benjannet, S., Schiller, P. W. and Chrétien, M. (1977a) Morphine-like activity of sheep $\beta$-lipotropin and its tryptic fragments. Can. J. Biochem. 55: 35-40. 
Seidah, N. G., Dragon, N., Benjannet, S., Routhier, R. and Chrétien, M. (1977b) The complete sequence of sheep $\beta$-endorphin. Biochem. biophys. Res. Commun. 74: 1528-1535.

Seidah, N. G., Chan, J. S. D., Mardini, G., Benjannet, S., Chrétien, M., Boucher, R. and Genest, J. (1979) Specific cleavage of beta-LPH and ACTH by tonin: release of an opiate-like peptide beta-LPH-(61-78). Biochem. biophys. Res. Commun. 86: 1002-1013.

Seidah, N. G., Hsi, K. L., Chrétien, M., Barat, E., Patthy, A. and Gráf, L. (1982) The primary structure of human $\beta$-lipotropin. FEBS Lett. 147: 267-272.

Seidah, N. G., Pélaprat, D., Rochemont, J., Lambelin, P., Dennis, M., Chan, J. S. D., Hamelin, J., Lazure, C. and CHRÉtIEN, M. (1984) Enzymatic maturation of pro-opiomelanocortin by anterior pituitary granules: a methodological approach leading to definite characterization of cleavage sites using HPLC and microsequencing. $J$. Chromatogr. in press.

Shu-Dong, T., Phillips, D. M., Halmi, N., Krieger, D. T. and Bardin, C. W. (1982) $\beta$-Endorphin is present in the male reproductive tract of five species. Biol. Reprod. 27: 755-764.

SMYth, D. G. and SNell, C. R. (1977a) Metabolism of the analgesic peptide lipotropin C-fragment in rat striatal slices. FEBS Lett. 78: 225-227.

SMYTH, D. G. and SNeLl, C. R. (1977b) Proteolysis of lipotropin C-fragment takes place extracellularly to form $\gamma$-endorphin and (methionine)enkephalin. Biochem. Soc. Trans. 5: 1397-1399.

SMYTH, D. G. and ZAKARIAN, S. (1978) N-Acyl derivatives of endorphins: biological properties and distribution. In: Characteristics and Function of Opioids, pp. 293-296, VAN ReE, J. M. and Terenius, L. (eds) Elsevier/North-Holland, Amsterdam.

Smyth, D. G. and Massey, D. E. (1979) A new glycopeptide in pig, ox and sheep pituitary. Biochem. biophys. Res. Commun. 87: 1006-1010.

SMYTH, D. G. and ZAKARIAN, S. (1979) Isolation and characterization of endogenous $[\alpha]-N$-acyl-derivatives of the C and $C^{\prime}$ of LPH. In: Endorphins in Mental Health Research, pp. 84-92, Usdin, E., BunNEY, W. C. and KLINE, N. S. (eds) MacMillan, New York.

SmYth, D. G. and Zakarian, S. (1980) Selective processing of $\beta$-endorphin in regions of porcine pituitary. Nature 288: 613-615.

SMYTH, D. G. and ZAKARIAN, S. (1982) $\alpha-N$-acetyl derivatives of $\beta$-endorphin in rat pituitary: chromatographic evidence for processed forms of $\beta$-endorphin in pancreas and brain. Life Sci. 31: 1887-1890.

Smyth, D. G., Austen, B. M., Geisow, M. J. and SNell, C. R. (1977) Lipotropin C-fragment: The fundamental opioid peptide in brain. In: Molecular Endocrinology, pp. 327-335, MACINTYRE, I. and SzELKE, M. (eds) Elsevier/North-Holland, Amsterdam.

Smyth, D. G., Austen, B. M., Bradbury, A. F., Geisow, M. J. and Snell, C. R. (1978) Biogenesis and metabolism of opiate active peptides. In: Centrally Acting Peptides, pp. 231-239, HugHES, J. (ed) MacMillan, New York.

Smyth, D. G., MasSey, D. E., Zakarian, S. and Finnie, M. D. A. (1979) Endorphins are stored in biologically active and inactive forms: isolation of $\alpha-N$-acetyl-peptides. Nature 279: 252-254.

SMYth, D. G., Smith, C. C. and ZaKarian, S. (1982) Isolation and identification of two new peptides related to $\beta$-endorphin. In: Advances in Endogenous and Exogenous Opioids, pp. 145-148, TAKAGI, H. and Simon, E. J. (eds) Kodansha/Elsevier, Tokyo and Amsterdam.

Spiess, J., Mount, C. D., Nicholson, W. E. and ORTH, D. N. (1982) $\mathrm{NH}_{2}$-terminal amino acid sequence and peptide mapping of purified human $\beta$-lipotropin: comparison with previously proposed sequences. Proc. natn. Acad. Sci. U.S.A. 79: 5071-5075.

Steiner, D. F., Kemmler, W., Tager, H. S. and Peterson, J. D. (1974) Proteolytic processing in the biosynthesis of insulin and other proteins. Fedn Proc. 33: 2105-2115.

Steiner, D. F., Kemmler, W., Tager, H. S., Rubinstein, A. H., Lernmark, A. and Zühlke, H. (1975) Proteolytic mechanisms in the biosynthesis of polypeptide hormones. In: Proteases and Biological Control, pp. 531-549, Reich, E., Rifkin, D. B. and Shaw, E. (eds) Cold Spring Harbor Lab., Cold Spring Harbor N.Y.

Steiner, D. F., Patzelt, C., Chan, S. J., Quinn, P. S., Tager, H. S., Nielsen, D., Lernmark, A., Noyes, B. E., Agarwal, K. L., Gabbay, K. H. and Rubinstein, A. H. (1980) Formation of biologically active peptides. Proc. R. Soc. Lond. 210: 45-49.

Suhar, A. and Marks, N. (1979) Purification and properties of brain cathepsin B: evidence for cleavage of pituitary LPH's. Eur. J. Biochem. 101: 23-30.

Sykes, J. E. C. and WIEgAnt, V. M. (1983) Release of $\alpha$-, $\gamma$-, and $\beta$-type endorphins from the rat neurointermediate lobe in vitro. Proc. of the 24 ih Dutch Fedn Meeting, abstr. 389.

Sykes, J. E. C., Wiegant, V. M. and DE WIED, D. (1983) Characterization of endorphins released from the rat neurointermediate lobe in vitro. Neurosci. Lett. suppl. 14: S364.

Tager, H. S., Emdin, S. O., Clark, J. L. and Steiner, D. F. (1973) Studies on the conversion of proinsulin to insulin. II. Evidence for a chymotrypsin-like cleavage in the connecting peptide region of insulin precursors in the rat. J. biol. Chem. 248: 3476-3482.

Takahashi, H., Teranishi, Y., Nakanishi, S. and Numa, S. (1981) Isolation and structural organization of the human corticotropin- $\beta$-lipotropin precursor gene. FEBS Lett. 135: 97-102.

TANAKa, K., NichOlsON, W. E. and ORTH, D. N. (1978a) The nature of the immunoreactive LPH's in human plasma and tissue extracts. J. clin. Invest. 62: 94-104.

Tanaka, K., Nicholson, W. E. and Orth, D. N. (1978b) Diurnal rhythm and disappearance half time of endogenous plasma immunoreactive $\beta$-MSH (LPH) and ACTH in man. J. clin. Endocr. Metab. 46: $883-890$.

Traficante, L., Rotrosen, J., Siekierski, J., Tracer, H. and Gershon, S. (1980) Enkephalin inactivation by $N$-terminal tyrosine cleavage: Purification and partial characterization of a highly specific enzyme from human brain. Life Sci. 26: 1697-1706.

Troy, C. M. and Musacchio, J. M. (1982) Processing of enkephalin precursors by chromaffin granule enzymes. Life Sci. 31: 1717-1720. 
Tsong, S. D., Phillips, D., Halmi, N., Liotta, A. S., Margioris, A., Bardin, C. W. and Krieger, D. T. (1982) ACTH and $\beta$-endorphin-related peptides are present in multiple sites in the reproductive tract of the male rat. Endocrinology 110: 2204-2206.

Uhler, M. and HerberT, E. (1983) Complete amino acid sequence of mouse pro-opiomelanocortin derived from the nucleotide sequence of pro-opiomelanocortin cDNA. J. biol. Chem. 258: 257-261.

Umezawa, H. and Aoyagi, T. (1977) Activities of proteinase inhibitors of microbial origin. In: Proteinases in Mammalian Cells and Tissues, pp. 637-662, BARETT, A. J. (ed.) Elsevier/North-Holland, Amsterdam.

VAN REE, J. M. and DE WIED, D. (1982) Neuroleptic-like profile of $\gamma$-type endorphins as related to schizophrenia. Trends pharmac. Sci. 3: 358-361.

Van Ree, J. M., De Wied, D., Bradbury, A. F., Hulme, E. C., Smyth, D. G. and Snell, C. R. (1976) Induction of tolerance to the analgesic action of lipotropin C-fragment. Nature 264: 792-794.

VAN REE, J. M., BoHUS, B. and DE WIED, D. (1380) Similarity between behavioral effects of des-tyrosine- $\gamma-$ endorphin and haloperidol and of $\alpha$-endorphin and amphetamine. In: Endogenous and Exogenous Opiate Agonists and Antagonists, pp. 459-462, WAY, E. L. (ed.) Pergamon Press, New York.

Van Ree, J. M., Verhoeven, W. M. A., Van PraAg, H. M. and de Wied, D. (1983) The use of the synthetic peptides $\gamma$-type endorphins in mentally ill patients. Ann. N.Y. Acad. Sci. 398: 478-495.

VAudry, H., Pelletier, G., GuY, J., Leclerc, R. and Jegou, S. (1980) Immunohistochemical localization of $y$-endorphin in the rat pituitary gland and hypothalamus. Endocrinology 106: 1512-1520.

Verhoef, J., Loeber, J. G., Burbach, J. P. H., Gispen, W. H., Witter, A. and de Wied, D. (1980) $\alpha$-Endorphin, $\gamma$-endorphin and their des-tyrosine fragments in rat pituitary and brain tissue. Life Sci. 26: $851-859$.

VERHOEF, J., WIEGANT, V. M. and DE WIED, D. (1982a) Regional distribution of $\alpha$ - and $\gamma$-type endorphins in rat brain. Brain Res. 231: 454-460.

Verhoef, J., WiEgANT, V. M. and DE WIED, D. (1982b) $\alpha$-Endorphin, $\gamma$-endorphin, and their des-tyrosine fragments: distribution in rat brain. In: Regulatory Peptides: From Molecular Biology to Function, pp. 69-74, Trabucchi, M. and Costa, E. (eds) Raven Press, New York.

Verhoef, J., Scholtens, H., VergeER, E. G. and WitTer, A. (1983) Des-Tyr ${ }^{1}-\gamma$-endorphin (DT $\gamma$ E) and des-enkephalin- $\gamma$-endorphin (DE $\gamma$ E): plasma profile and brain uptake after systemic administration in the rat. submitted.

Verhoeven, W. M. A., Van Praag, H. M., Van Ree, J. M. and DE Wied, D. (1979) Improvement of schizophrenic patients by treatment with des-Tyr $\mathrm{r}^{1}-\gamma$-endorphin (DT $\gamma$ E). Arch. gen. Psychiat. 36: 294-298.

Verhoeven, W. M. A., Van Ree, J. M., De Wied, D. and VAN PraAg, H. M. (1981) $\gamma$-Type endorphins and schizophrenia. Arch. gen. Psychiat. 38: 1182-1183.

VuOLTEENAKO, O. and LePPÄLUOTO, J. (1983) Isolation and characterization of $\beta$-endorphin-(1-18) from human autopsy pituitaries. Acta Endocr. 103, suppl. 256: abstr. 244.

Wang, X. -C., Burbach, J. P. H. and Verhoef, J. (1983) Proteolysis of adrenocorticotropin in brain: characterization of cleavage sites by peptidases in synaptic membranes and formation of peptide fragments. J. biol. Chem. 258, 7942-7947.

Weber, E., Evans, C. J., Chang, J-K. and Barchas, J. D. (1981) Acetylated and nonacetylated forms of $\beta$-endorphin in rat brain and pituitary. Biochem. biophys. Res. Commun. 103: 982-989.

Whitfield, P. L., SeEburg, P. H. and ShiNe, J. (1982) The human pro-opiomelanocortin gene: organization sequence, and interspersion with repetitive DNA. DNA 1: 133-143.

Wifdemann, E., Saito, T., Linfoot, J. A. and Ll, C. H. (1979) Specific radioimmunoassay of human $\beta$-endorphin in unextracted plasma. J. clin. Endocr. Metab. 49: 478-480.

Wiegant, V. M., Verhoef, J., Burbach, J. P. H., Van Amerongen, A., Gaffori, O., Sitsen, J. M. A. and DE WIED, D. (1983a) $\alpha-N$-Acetyl- $\gamma$-endorphin: a non-opioid neuropeptide with behavioural activity. Proc. of the 24th Fed. Meeting, Leiden, abstr. 459.

Wiegant, V. M., Verhoef, J., BurbaCh, J. P. H. and Van AMERongen, A. (1983b) Characterization of $N^{\alpha}$-acetyl- $\alpha$-endorphin from rat neurointermediate lobe and its distribution in pituitary and brain. Life Sci. 33, 125-128.

ZAKARIAN, S. and SMYTH, D. G. (1979) Distribution of active and inactive forms of endorphins in rat pituitary and brain. Proc. natn. Acad. Sci. U.S.A. 76: 5972-5976.

ZAKARIAN, S. and SMYTH, D. G. (1982a) $\beta$-Endorphin is processed differently in specific regions of rat pituitary and brain. Nature 296: $250-252$.

ZAKARIAN, S. and SMYTH, D. G. (1982b) Distribution of $\beta$-endorphin-related peptides in rat pituitary and brain. Biochem. J. 202: 561-571. 